\title{
LA INDUSTRIA TEXTIL DE ZARAGOZA ANTES DE $1500^{1}$
}

\author{
THE TEXTILE INDUSTRY IN ZARAGOZA BEFORE 1500
}

\section{GERMÁN NAVARRO ESPINACH Universidad de Zaragoza}

\begin{abstract}
Resumen: La industria de la lana en Zaragoza necesita un estudio específico que aclare su función en la economía de la ciudad durante los siglos XIII-XV. Las ordenanzas textiles están editadas pero todavía no se han analizado otras noticias existentes en las actas municipales y notariales. Se presenta aquí el primer estado de la cuestión conocido sobre este tema ilustrado con nueva documentación inédita. Se valora también el papel menos relevante que tuvo la industria sedera local.
\end{abstract}

Palabras clave: Industria textil; Lana; Seda; Economía urbana; Zaragoza; Reino de Aragón; Siglo XV.

\begin{abstract}
The woollen industry in Zaragoza needs a specific study to clarify its role in the economy of the city during the XIIIth-XVth centuries. The rules of textile guilds are edited but other kind of records still has not been compared. We report here the first research which strikes a balance about this subject. It is also appreciated the smaller role of the local silk industry in the same context.
\end{abstract}

Key words: Textile industry; Wool; Silk; Urban economy; Zaragoza; Kingdom of Aragon; 15th century.

\section{SUMARIO}

1. Población y mercado de trabajo en la Zaragoza del siglo XV.- 2. Análisis de las ordenanzas de los oficios de la lana.- 3. Noticias inéditas procedentes de la documentación municipal y notarial.- 4. Valoración de las dimensiones de la industria sedera.- 5. Censo de artesanos de la lana de la ciudad de Zaragoza (1439-1496).

\section{POBLACIÓN Y MERCADO DE TRABAJO EN LA ZARAGOZA DEL SIGLO XV}

Cuando Jerónimo Münzer visitó la ciudad de Zaragoza a principios del mes de febrero de 1495 describía de la siguiente manera sus fuentes de riqueza: "Tiene muchos mercaderes, porque abunda, como dije, el azafrán,

${ }^{1}$ El presente estudio se integra en el programa de actividades del Grupo de Investigación de Excelencia C.E.M.A. (Centro de Estudios Medievales de Aragón) de la Universidad de Zaragoza y, en concreto, es un resultado directo del proyecto interuniversitario Migraciones, elites economicas e identidades culturales en la Corona de Aragón (1350-1500), subvencionado por la Dirección General de Ciencia y Tecnología durante 2005-2008' (Ref. HUM200504804/HIST). Agradezcó a la profesora María Isabel Falcón la lectura generosa de este artículo antes de su publicación. 
el trigo, lana de la mejor calidad, la gualda, el ganado, la miel, la cera y otros frutos, además del cuero, excelentemente curtido, para zapatos y toda clase de calzado" ${ }^{2}$. La mención al negocio lanero y la producción de una planta tintórea como la gualda dan pie a pensar en la actividad textil como un sector relevante del que vivían muchas familias en la ciudad a finales de la Edad Media si no antes. Al año siguiente de la visita de Münzer, durante mayo y julio de 1496, el fogaje general del reino proporciona la cifra de población fiscal correspondiente a la ciudad de Zaragoza de aquel entonces: 3.983 fuegos $^{3}$. Se había duplicado la población oficial en relación con las 2.480 casas de 1369 . Pero el fogaje general del reino de 1405 ordenado por las cortes de Maella todavía ofrecía una cifra de 2.864 fuegos, lo que sugiere que el mayor incremento demográfico vino más tarde. De hecho, se alcanzaron de manera estable los cuatro mil fuegos durante los recuentos fiscales de 1472 y $1496^{4}$. Por estas mismas fechas se computaba más del doble de esa cifra de contribuyentes en la ciudad de Valencia (8.840 fuegos en 1489) y una cantidad no tan superior en Barcelona (5.749 en 1497) ${ }^{5}$.

Una vez más no se debe despreciar el hecho de que en los recuentos fiscales parte importante de la población no está comprendida por motivos de marginalidad o tránsito. El ejemplo del hospital más importante de Zaragoza puede resultar didáctico por su contundencia. El 25 de noviembre de 1471, mosén Majones, clérigo regidor del Hospital de Señora Santa María de Gracía, llamado también del Rey, presentó un escrito a los jurados zaragozanos bastante elocuente:

...muchas grandes congoxas en que la dicha casa e pobres de aquella son
consumydos por las grandes e inmoderadas expensas e gastos que ordi-
nariament a causa del grant numero de pobres, enfermos, feridos, insen-
sados e criaturas de leche ad aquella declinantes. E la poca rebuda e ins-
tancia de la dicha casa que buenament no abasta a los salarios de nodri-
ças, que ordinariament ni ha de sixanta en setanta, e de alli assuso, de
manera que por la mucha pobreza de aquella van muchos de los dichos
pobres, criaturas menores, ya fuera de leche e otros insensados, quasi
despullados e descalços, estan en punto de perecer de frio, e los fechos
assi de los enfermos como de los otros stan depauperados de ropa que
quasi no y han que meter encima. Lo qual los dichos jurados havian vis-
to a oxo el sabado mas cerqua passado ensemble con el prior de la Seu e
maestre Lana. Los quales movidos de piedat, vista la gran miseria e ne-

${ }^{2}$ J. MÜnZer, Viaje por España y Portugal, Madrid, Polífemo, 2002, p. 291. ${ }^{3}$ A. SERRANO MONTALVO, La población de Aragón según el fogaje de 1495, 2 vols., Zara-
goza, 1997, tomo I, pp. 67-115. Zaragoza tiene 3.983 fuegos en 1496 según Serrano o 3.969 Según M.I.'FALCÓN PÉREZ, Aportacion al estudio de la población aragonesa a finales del siglo XV, "Aragón en la Edad Media", V (1983), pp. 255-302 (véase el índice alfabético de lugares y fuegos).

${ }^{4}$ S. LOZANO GARCía, La población de la ciudad de Zaragoza en los siglos XIV y XV en el volumen de J.A. Sesma Munoz y C. Laliena Corbera (coordinadores), La población de Aragón en la Edad Media (siglos XIII-XV). Estudios de demografía historica, Zaragoza, Grupo CEMA y Leyere Editorial, 2004, pp. 471-518.

${ }^{5}$ J.A. SESMA MUÑOZ, La población urbana en la Corona de Aragón (siglos XIV-XV) en las actas de la XXIX Semana de Estudios Medievales de Estella (2002), Las sociedades urbanas en la España medieval, Pamplona, 2003, pp. 151-193. 
cessidat del dicho spital e de los pobres, enfermos e otros de aquel, ellos con otros que alli se fallaron plegaron para la dita casa cient e XV florines $^{6}$.

Está claro que el fogaje no buscaba censar a todas estas personas humildes, sin embargo, para hacer una interpretación correcta del volumen demográfico de Zaragoza hay que tomarlas en consideración, aparte del tantas veces recurrido coeficiente o componente humano por fuego. Lo que se descubre con este ejemplo es una gran bolsa humana de pobreza y miseria, propia de una ciudad en expansión. No parece que sea una exageración del clérigo que rige el hospital para lograr más recursos, puesto que los propios jurados lo han visto con sus propios ojos. La imagen obtenida es la de una falta latente de expectativas de trabajo para todos, porque mucha gente estaba enferma o hambrienta, no tenía con qué vestirse para protegerse del frío, y se abandonaban muchos niños y niñas recién nacidos. La cifra de sesenta a setenta nodrizas que no pueden dar abasto para amamantar a las criaturas del hospital está cargada de trascendencia para el análisis demográfico.

El mercado de trabajo urbano debió saturarse lentamente a lo largo del siglo XV. El 19 de octubre de 1442 las autoridades zaragozanas creaban el cargo de "corredor de firmar moços" en la persona de Juan de Monzón, vecino de la ciudad, quien se ocuparía de colocar y recolocar a los jóvenes, tal vez para que no fuesen deambulando sin oficio ni beneficio por doquier, con el peligro que ello podía suponer para el mantenimiento del orden público. En ese sentido, en la documentación notarial se reflejan bastantes contratos de sirvientas y aprendices, sin olvidarnos de la compraventa de trabajadores esclavos. Además figuran muchas personas como residentes provisionales en la ciudad, lo que quiere decir que las franquezas y vecindades concedidas por las autoridades municipales a los forasteros que quieren vivir en Zaragoza no son un reflejo global de la movilidad poblacional, como ya se ha tenido oportunidad de demostrar respecto a la emigración aragonesa a Valencia ${ }^{8}$, o con la colonia italiana estable que habitaba en Zaragoza a finales del siglo XV, totalmente ajena a los avecindamientos ${ }^{9}$. Fenómenos todos ellos sólo comprensibles en profundidad a partir de censos prosopográficos exhaustivos que cruzan en una base de datos

${ }^{6}$ Archivo Municipal de Zaragoza (en adelante AMZ), Actos Comunes, 5 (1470-1471). Publicado por M.I. FALCÓN PÉREZ, Sanidad y beneficencia en Zaragoza en el siglo XV, "Aragón en la Edad Media”, III (1980), pp. 183-226, doc. IV, p. 217.

${ }^{7}$ Archivo Municipal de Zaragoza, Actos Comunes, 4 (1442).

${ }^{8}$ G. NAVARro Espinach, Política municipal y avecindamientos. Análisis de la emigración aragonesa a Valencia (1308-1526), en las actas del seminario Demografía y sociedad en la España bajomedieval, Universidad' de Zaragoza (10-11 de mayo de 2001), Zaragoza, 2002, pp. 97-128.

${ }^{9}$ G. NAVARRo EsPinaCh; M.T. SAuco Álvarez; S. Lozano Gracia, Italianos en Zaragoza (siglos XV-XVI), "Historia. Instituciones. Documentos", 30 (2003), pp. 301-398. 
fuentes documentales heterogéneas, tal y como se ha aplicado en otros contextos ${ }^{10}$.

Dicho todo esto, la pregunta que subyace es otra. ¿Ese fogaje realizado al poco de la visita de Münzer reproduce un número alto de artesanos especializados en la industria textil de Zaragoza en sintonía con lo que contaba el viajero alemán? ¿Cuántos contribuyentes declaran tener esta ocupación? La cifra exacta es de 93 fuegos con este tipo de oficios entre los 3.983 del total. La industria de la lana posee una calle propia en la parroquia de San Pablo (Carrera de la Filaça) y hasta 81 fuegos declarados (35 pelaires, 24 tejedores, 10 bajadores de paños, 3 carderos, 3 tintoreros, 2 hilanderas, 2 laneros y 2 peinadores). Se han introducido los nombres y domicilios de sus titulares en el censo prosopográfico confeccionado al final del presente artículo con el objetivo de completarlos con otras informaciones disponibles sobre el artesanado lanero de la ciudad. En contraste y en un segundo plano aparece una docena de hogares dedicados a la industria sedera con oficios habituales en el empleo de dicha materia prima, según los conocimientos existentes sobre el ámbito tecnológico mediterráneo de aquella época ${ }^{11}$. Se trata de 5 pasamaneros, 3 capeleros, 2 cedaceros, 1 parchero y 1 velero, además de un área específica ocupada en la fabricación de telas de cedazos de seda, sita también en la parroquia de San Pablo (La Cedacería).

Así, pues, hay un núcleo central de casas en la ciudad implicadas directamente en el negocio textil, hasta el punto de que la identidad profesional de sus ocupantes queda bien reflejada en el fogaje, a pesar de que a veces sea con la ambigüedad propia de expresiones como las hilanderas de Lobera o el tinte de Mateo Benet, cuyo componente humano otra vez se escapa. Sin olvidar que es un hecho muy comprobado que la actividad textil estaba omnipresente de forma clandestina o implícita en la inmensa mayoría de los hogares de las ciudades y del campo medievales, con la implicación masiva de la mano de obra femenina, silenciosa en las fuentes escritas pero bien visible en la iconografía de la época.

Los datos procedentes de algunas catas sobre la contratación laboral y el mercado de la mano de obra en Zaragoza durante los siglos XVXVI también confirman el protagonismo numérico del sector textil en la industria local. De los 322 contratos de aprendizaje correspondientes a 37 oficios distintos que fueron localizados por la profesora María Isabel Falcón ${ }^{12}$ para el período $1400-1493$ entre la clientela de diecisiete notarios za-

${ }^{10} \mathrm{G}$. NAVARRo ESPINACH; D. Igual Luis; J. APARICI MARTí, Los inmigrantes y sus formas de inserción social en el sistema urbano del reino de Valencia (siglos XIV-XVI), "Revista d'Història Medieval", 10 (1999), pp. 161-199.

${ }^{11} \mathrm{G}$. NAVARRO ESPINACH, El arte de la seda en el Mediterráneo medieval, "En la España Medieval", 27 (2004), pp. 5-51. Para el caso valenciano véase del mismo autor Los orígenes de la sedería valenciana (siglos XV-XVI), Ayuntamiento de Valencia, 1999.

${ }^{12}$ M.I. FAlCón PÉREZ, Fuentes para la historia del trabajo en la Baja Edad Media aragonesa, "Actas de las Jornadas sobre Metodología de la Investigación Científica sobre Fuentes Aragonesas" (Monzón, 1985), Zaragoza, 1986, pp. 165-177. 
ragozanos diferentes (en total 135 protocolos consultados), las especialidades textiles devienen prácticamente un tercio del total de contratos (48 pelaires, 19 bajadores de paños, 13 tejedores, 6 tintoreros, 5 sogueros, 4 carderos, 3 veleros, 1 tejedor de sacos y 1 trapero). Otro sondeo anterior realizado hace más de cuarenta años por el profesor Ángel San Vicente ${ }^{13}$ para su tesis doctoral en Derecho sobre los contratos de aprendizaje efectuados por el padre de huérfanos de Zaragoza confirmaba ya ese predominio latente de los pelaires y de los otros artesanos de la lana en el acceso de los jóvenes al mercado de trabajo del Quinientos, con la presencia además de casi una veintena de oficios distintos dedicados al negocio y arte de la seda: vellutero, capelero, cedacero, crespador de velos, guardamacilero, maestro de hacer calzas de aguja de seda, mercader de sedas, parchero, prensador de sedas, prensador de terciopelos, sedero, tejedor de damasco, tejedor de seda, tejedor de tafetán, tejedor de tocas, tejedor de velos, torcedor de seda y velero.

Por fin, después del año 1500 se ha demostrado con rotundidad la importancia que tenía el trabajo de la lana en la Zaragoza del siglo XVI frente a un desarrollo mucho más limitado del lino y del cáñamo mediante el análisis prosopográfico de unos 2.000 artesanos identificados entre la clientela de hasta veinte notarios del siglo XVI y los registros de actos comunes del gobierno municipal desde 1500, aparte de otros documentos complementarios. Parece ser que la producción de la pañería tradicional zaragozana se vio influída por los centros textiles de Perpiñán y Valencia, especialmente el segundo, con el que hubo contactos intensos que se canalizaron esencialmente a través del comercio de la lana. Destacada fue asimismo la presencia de paños valencianos, hasta el punto de ser habitual en muchas de las compañías que se crearon a lo largo del siglo XVI que se dispusiese de un factor en Valencia encargado de adquirirlos. Además, diversos pelaires procedentes de Perpiñán y Valencia llegaron a Zaragoza para instalarse a veces de forma definitiva, de manera que los contactos con ambas ciudades no se redujeron a la exportación de lana e importación de paños, sino que hubo una clara transferencia de mano de obra y de saberes técni$\cos ^{14}$. Y de forma paralela, el análisis del arte del bordado en el citado siglo XVI ha entrado por primera vez en el estudio de la industria sedera local y en su importancia en la confección de la vestimenta litúrgica de la época, planteando también el tema de los orígenes del sector en la Edad Media ${ }^{15}$. De ahí que parezca muy pertinente tratar de responder aquí a la pregunta: ¿Qué dimensiones alcanzaron los negocios de la lana y de la seda en Zaragoza antes de 1500 ?

\footnotetext{
${ }^{13}$ A. SAN VICENTE PINO, El oficio del padre de huérfanos en Zaragoza, Universidad de Zaragoza, 1965, pp. 131-151.

${ }^{14} \mathrm{P}$. DESPORTES BIELSA, La industria textil en Zaragoza en el siglo XVI, Zaragoza, Institución Fernando el Católico, 1999, pp. 195-199.

${ }^{15} \mathrm{~A} . \mathrm{M}^{\mathrm{a}}$. ÁGREDA PINO, Los ornamentos en las iglesias zaragozanas, siglos XVI-XVIII. Aportaciones al estudio de los talleres de bordado y las artes textiles en Aragón en la Edad Moderna, Zaragoza, Institución Fernando el Católico, 2001, pp. 113-138.
} 
Lo cierto es que hace tiempo que los datos de la población y el mercado de trabajo condujeron a la realización de un primer balance sobre las investigaciones existentes en torno al sector manufacturero en la ciudad de Zaragoza ${ }^{16}$ para establecer pautas iniciales de comparación con los otros centros artesanales del reino, tanto de ámbito urbano como rural, los cuales se dejaban entrever a la luz de indicios documentales de tipología variada ${ }^{17}$. En algún caso ha sido posible entrar en estudios más profundos como sucede con la industria textil de la ciudad de Terue ${ }^{18} \mathrm{u}$ otros sondeos efectuados más recientemente sobre manufacturas rurales en la bailía de Cantavie$\mathrm{ja}^{19}$. Se ha interpretado también un proceso del tribunal de la Inquisición aragonesa, fechado en octubre del repetido año 1500, contra el sedero valenciano Francisco Natera y otros artesanos conversos habitantes de la ciudad que habían huido con los bienes del mudéjar Yusuf Xama, propietario de un torno de seda. Entre los testigos que declaran sobre el paradero de los fugitivos están Francisco de Porres o Alonso de Aragón, tejedores de terciopelo habitantes de Zaragoza ${ }^{20}$. En último extremo, el significado de la investigación puesta en marcha radica en ahondar desde el sector textil en un mayor conocimiento de las fuentes de riqueza más importantes que sirvieron de sustento a las familias zaragozanas del siglo XV en aras de una mejor comprensión de su sociedad y su cultura.

\section{ANÁLISIS DE LAS ORDENANZAS DE LOS OFICIOS DE LA LANA}

Para empezar se considera necesario revisar y comentar con detalle los textos de ordenanzas conocidos sobre la industria de la lana en Zaragoza, cuyo desarrollo normativo fue notable desde finales del siglo XIII. Con ese guión previo se entenderán mejor todas las otras noticias procedentes

\footnotetext{
${ }^{16} \mathrm{G}$. NAVARRO ESPINACH, La industria precapitalista en Zaragoza (siglos XIV-XV), "Terceras Jornadas de Estudios sobre Aragón en el umbral del siglo XXI", Caspe, 15-17 diciembre 2000 .

${ }^{17}$ G. NAVARro Espinach, El desarrollo industrial de Aragón en la Baja Edad Media, "Aragón en la Edad Media”, XVII (2003), pp. 179-212.

${ }^{18} \mathrm{G}$. NAVARRO ESPINACH; J. APARICI MARTÍ, La producción textil en Teruel medieval, "Teruel. Revista del Instituto de Estudios Turolenses", 88-89, vol. II (2000-2002), pp. 73 100. Véase también el artículo anterior de M.I. FALCÓN PÉREZ, La industria textil en feruel a finales de la Edad Media, "Aragón en la Edad Media", X-XI (1993), pp. 229-250.

${ }^{19} \mathrm{G}$. NAVARRO ESPINACH; J. APARICI MARTÍ, Villarluengo, un lugar de la bailía de Cantavieja en el siglo XV, "Aragón en la Edad Media", XX, Homenaje a la profesora María de los Desamparados Cabanes Pecourt, en prensạ. Está preparándose la edicion de G. NAVARRO ESPINACH, El libro de la bailía de Cantavieja y las cuentas del concejo de Mirambel (siglo $X V)$. Departamento de Historia Medieval de la Universidad de Zaragoza y Grupo de Excelencia C.E.M.A., Colección Textos e Instrumentos de Investigación.

${ }^{20} \mathrm{G}$. NAVARRO ESPINACH; J. ABELLA SAMITIER, El proceso contra Francisco Natera, sedero valenciano habitante de Zaragoza (año 1500), "IV Jornadas de Estudios sobre Aragón en el umbral del siglo XXI, Panticosa (Huesca), 2001, actas sin publicar. Véase el texto del proceso publicado y estudiado en G. NAVARRO ESPINACH, Los musulmanes y la ruta de la seda entre Oriente y Occidente en el libro de F. Nuez (editor), La herencia árabe en la agricultura y el bienestar de Occidente, Valencia, Fundación La Huella Arabe y Universidad Politécnica de Valencia, 2002, pp. 283-328.
} 
de fuentes municipales y notariales. En ese sentido, en 1288 el rey Alfonso III estableció unas normas para los judíos traperos de Zaragoza que tenían en sus casas paños de Francia. Dichas casas estaban situadas entre la Picotería y la Correería junto a los traperos cristianos $^{21}$. La presencia de tejidos franceses en Zaragoza entraba en consonancia con lo que venía ocurriendo por aquellos años en Barcelona y Valencia, el origen de cuyas industrias laneras tuvo que ver directamente con la presencia de artesanos y mercaderes franceses y la imitación de su tecnología ${ }^{22}$. Paralelamente, en 1291, los procuradores de los "homens bonos del mester de los texidores de la ciudat de Saragossa" participaban ya en un acuerdo con otros oficios y parroquias para evitar disputas entre ellos, prometiendo mantener la paz y la justicia y evitar las luchas de bandos ${ }^{23}$. Ya existían por aquellas fechas colectivos de traperos y tejedores reconocidos por el poder en sintonía con un fenómeno generalizado de desarrollo corporativo por parte del artesanado aragonés ${ }^{24}$.

Poco tiempo después, en 1311, Jaime II dictaba en las cortes de Daroca un fuero prohibiendo la existencia de cofradías de menestrales, exceptuando aquellas que tuviesen fines piadosos. En el documento se citaban entre otras las de "textores" y "traperii" 25 . Ese mismo año, el 18 de mayo, el monarca atendió una queja de los habitantes de la parroquia de Santa María la Mayor de Zaragoza relativa a los ruidos y molestias que causaban las ruedas y mazas de los batanes ubicados en algunas casas de su distrito: “...ratione et strepitus ictium seu percussionum qui fiunt cum maçis que sunt in quibusdam domibus situatis in dicta parrocha" ${ }^{26}$. A la existencia de estos molinos pañeros situados en la ribera del Ebro a principios del siglo XIV - tal vez los tres que se conocen posteriormente ${ }^{27}$ - se sumaban también las tintorerías, como se deduce de dos órdenes del mismo Jaime II en 1318 y 1319 para que el merino de la ciudad permitiese a sus habitantes teñir en sus casas todo tipo de paños y en todos los colores salvo el índigo,

\footnotetext{
${ }^{21}$ M.I. FALCÓN PÉREZ, Ordenanzas y otros documentos complementarios relativos a las Corporaciones de oficio en el reino de Aragón en la Edad Media, Zaragoza, Institución Fernando el Católico, 1997, doc. 12.

${ }^{22}$ A. RIERA Melis, La aparición de las corporaciones de oficio en Cataluña (1200-1350) en las actas de la XIX'Semana de Estudios Medievales de Estella (1992), Cofradías, gremios, solidaridades en la Europa medieval, Pamplona, 1993, pp. 285-318; y J. BORDES GARCIA, Desarrollo industrial textil y artesanado en Valencia de la conquista a la crisis (1238-1350), Valencia, Comité Económico y Social de la Comunidad Valenciana, 2006.

${ }^{23}$ FAlCón, Ordenanzas, citado, doc. 13.

${ }^{24}$ J.A. SESMA MUÑOZ, L'organizzazione del mondo urbano e le corporazioni nella Corona d'Aragona (XIII secolo) en Tra economia e politica: Le corporazioni nell'Europa Medievale,

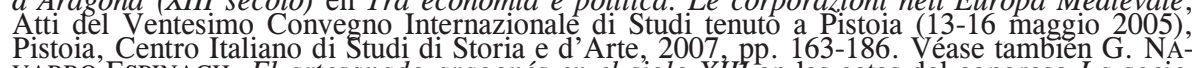
VARRO ESPINACH, El artesanado aragonés en el siglo XiII en las actas del congreso La sociedad en Aragón y Cataluña en el reinado de Jaime I (1213-1276), Zaragoza, Institución Fernando el Católico, 14-16 de mayo de 2008, en prensa.

${ }^{25}$ FALCón, Ordenanzas, citado, doc. 27.

${ }^{26}$ Ibídem, doc. 31.

${ }^{27}$ En la segunda mitad del siglo XIV se han identificado por lo menos tres batanes. Véase J.P. BARRAQUE, Saragosse à la fin du Moyen Age. Une ville sous influence, París-Montréal, L'Harmattan, 1998, pp. 213-214.
} 
sin tener que acudir al tinte real, es decir, "in caldera nostra dicte civitatis", siguiendo una costumbre antigua de Zaragoza ${ }^{28}$.

Por aquellos mismos años las poblaciones más importantes del reino que estaban más cercanas a Zaragoza poseían oficios de la lana con ordenanzas propias, como era el caso de los tejedores de Daroca que en 1329 o 1336 elaboraban "pecias seu sayales de lana" y lavaban dicha lana en las acequias $^{29}$. Asimismo, en Calatayud en 1347 se confirmaba la existencia de muchos tejedores "in dicta villa et eius aldeis tam per christianos quam per sarracenos et judeos exercetur per quosdam texitores et alias personas qui vel que pannos lane et lini ac aliorum generum lanifici" 30 . Precisamente, un siglo después, las ordenanzas del tinte de Calatayud de 1440 aludían como modelo de referencia a la ciudad de Zaragoza: “...que el arrendador e tinturero sea tenido de tenyr panyos e lanas segund la ley que la dita ciudat li dara, las quales leyes et muestras sian las que trayeran de Çaragoça e segunt que los colores que se fazen en Çaragoça”. Los precios también debían ajustarse a los establecidos por la capital del reino ${ }^{31}$.

Hacia 1443, la industria lanera en Zaragoza estaba en auge a tenor de cierto estatuto que prohibía a los hiladores ambulantes ejercer su oficio ante las casas de los vecinos de Zaragoza. Se habla de "personas filantes con ruedas e tornos, canyamos et otras filaças por las carreras e plaças publicas de la dita ciudat" que molestaban al vecindario ubicándose en las puertas de sus domicilios ${ }^{32}$. Debe subrayarse el hecho de que las primeras ordenanzas conocidas del oficio de los pelaires están fechadas a finales de esa década, en 1449, aludiendo sin embargo a unas "ordinaciones antigas que fueron dadas a los pelayres e texidores de la dita ciudat" ${ }^{33}$. La fecha de la fundación del oficio queda en la incertidumbre pues no se indica. De su lectura se descubre la oferta principal de tejidos que confeccionaban, a saber, cadines, escais o retales (paños escabezados), frisones, trapos mezclados de lana y lino, o trapos a la vervina, con clara influencia de la pañería francesa. Es también importante la alusión que existe a la figura del "senyor del trapo", es decir, a la persona que vende o hace vender "a barata" esos tejidos con encargos a domicilio para el hilado de la lana o la confección de los paños, tema ampliamente estudiado en Valencia como detonante de la acción de los mercaderes-empresarios en la industria textil ${ }^{34}$. Lo cierto es que a partir de esos estatutos de los pelaires de mediados del siglo XV el ciclo ordenancista de los oficios de la lana se disparó en la ciudad de Zaragoza como efecto de la efervescencia de dicha industria.

\footnotetext{
${ }^{28}$ FALCón, Ordenanzas, citado, docs. 46 y 47.

${ }^{29}$ Ibídem, docs. 57, 63, 73 y 85.

${ }^{30}$ Ibídem, doc. 71

${ }^{31}$ Ibídem, doc. 134.

${ }^{32}$ Ibídem, doc. 143.

${ }^{33}$ Ibídem, doc. 159.

${ }^{34}$ Véase G. NAVARRO ESPINACH, Los negocios de la burguesía en la industria precapitalista valenciana de los siglos XIV-XVI, "Revista d'Història Medieval", 11 (2000), pp. 67-104.
} 
En 1454 se fundó la cofradía de los bajadores de paños bajo la advocación de Santa Petronila con una nómina de 12 artesanos $^{35}$. Los usantes de este oficio lanero cortaban los paños sobre tableros en las calles o en el interior de los talleres, precisando licencia de sus veedores para tener tablero y practicar su profesión. En 1458 se otorgaron nuevas ordenanzas al oficio de tejedores de lana de la ciudad de Zaragoza ${ }^{36}$, presentadas a los jurados de la ciudad por los dos veedores y una docena de artesanos de dicha corporación y, como se vió después, los tejedores de Huesca imitaron al pie de la letra estos estatutos. El contenido de los mismos deja entrever algunas informaciones significativas. Para empezar, existían normas más antiguas que estaban vigentes, "las ordinaciones antigas que fueron dadas a los texidores de la dita ciudat" que, de hecho, estaban siendo incumplidas por diversas personas. A pelaires y mercaderes - los señores de los paños- no se les permitiría que siguiesen falsificando trapos ni obrajes de lana suyos ni ajenos de dentro o de fuera del reino de Aragón, ya que “...el dito officio del obrage de la lana es venido quasi en total destruction. Et esto sia causa la gran multitut de los trapos siquiere obrages de lana foranos e estrangeros de la dita ciutat que diversos mercaderes et otras personas trayen continuament a la dita ciudat". Para evitarlo todo paño elaborado por los tejedores del oficio tendría "hun senyal de Çaragoça por tal que sia conoscido en todo lugar que s'es texido en Çaragoça".

Tampoco pelaire ni tintorero alguno podría tener telares ni tejer por su cuenta sino había obtenido antes la licencia del oficio de tejedores, de manera que quienes no cumpliesen con este precepto deberían "desparar las perchas o telares" o correrían el riesgo de que los veedores entrasen en sus casas y los derrocasen. Igualmente, se da a entender que ciertos tejedores trabajaban en "algunos lugares escondidament" por lo que todos los miembros del oficio deberían ejercerlo en lugar donde pudieran ser vistos, con las puertas abiertas de sus casas si trabajaban en el interior de las mismas, prohibiendo "texir ni fer texir fuera de la ciudat de Çaragoça" por encargo de mercaderes o de judíos. Respecto a estos últimos, en 1459, el rey, conocedor del derecho de las autoridades municipales zaragozanas de regular los oficios relacionados con la industria textil, prohibe hacer ordenanzas para los tejedores judíos de la misma y mucho menos impedirles el ejercicio de su oficio ${ }^{37}$. En este último año 1459 se produjo la compra del molino trapero llamado de Almargen, sito en la acequia de Urdán, por parte de la cofradía de pelaires y bajadores de Santa María de Altabás. El edificio constaba de tres pilas, tres ruedas y una caldera ${ }^{38}$.

En 1460 la descripción del oficio de pelaires de la ciudad de Zaragoza "qui es uno de los grandes officios de aquella, ende reportava grant

\footnotetext{
${ }^{35}$ M.I. FALCÓN PÉREZ, La fundación de una cofradía gremial: la de los bajadores de paños de Zaragoza, "Anuario de Estudios Medievales", 18 (1988), pp. 563-573.

${ }^{36}$,M.I. FALCón, Ordenanzas, cit., docs. 140, 143, 159, 161, 167, 179, 202.

${ }^{37}$ Ibídem, doc. 181.

${ }^{38}$ Ibídem, docs. 186, 188, 189 y 191.
} 
proveyto et honor" traduce sin embargo cierta sensación de decadencia a ojos de sus miembros, los cuales aluden a la mala calidad de las piezas confeccionadas "et por esta razon el dito officio de la perayria es venido en grant disminucion". En 1461, el rey Juan II reconocía que de poco tiempo a esa parte se cometía gran fraude en el comercio de trapos. Unas ordenanzas municipales de 1463 sobre los paños de lana aludían a tejidos clandestinos procedentes tanto de fuera del reino como de los barrios, aldeas, lugares y términos de la ciudad, donde se fabricaban paños menores de peine $12^{\circ}$, vervines y escais por encargo de quienes "vendran o vender faran o barataran o baratar faran lanas" 39 . En idéntica dirección insisten los nuevos estatutos de los pelaires zaragozanos del año 1466 cuando se refieren a que "muytos mercaderes, botigueros e otras personas muytas vegadas han recusado e recusan servar los ditos capitoles" y por ese motivo se ordenaba a los mercaderes, tenderos, pañeros y cualesquiera otras personas que manifestasen sus tejidos de lana tanto aragoneses como foráneos ante los veedores del oficio. Si se encontrasen cadines menores de peine $12^{\circ}$, vervines menores de $13^{\circ} \mathrm{u}$ otros paños menores de $14^{\circ}$ falsificados como si fuesen de mayor obraje serían requisados por los veedores ${ }^{40}$. Son nuevas noticias que confirman la intervención incontrolada del capital comercial en la esfera de la producción textil zaragozana, en clara contradicción con la pretensión de monopolizar el mercado por parte de los pequeños productores autónomos que constituyen la mayoría absoluta del artesanado corporativo en el sector lanero de la ciudad.

A finales del siglo $\mathrm{XV}$, a esa situación que convulsiona el mercado textil de Zaragoza se le añade el enfrentamiento entre los oficios de tejedores y pelaires por la mutua intromisión en competencias técnicas. En 1492 el rey dictaba una sentencia en un pleito mantenido entre ambas corporaciones en la que prohibía a los tejedores tener perchas de pelaires y a éstos tener telares en sus casas ${ }^{41}$. Llama la atención también cierto proceso incoado en 1494 ante los jurados de la capital por los pelaires mayordomos de la cofradía de Santa María de Altabás contra uno de ellos, en el que se incluyen nuevas ordenanzas textiles y un listado de hasta 28 artesanos miembros de la cofradía ${ }^{42}$. La conflictividad y los problemas del sector se extienden también a la dinámica interna de sus oficios. En ese sentido, merece la pena observar algunas informaciones vertidas en determinados pasajes de este proceso. Para empezar, se dice que la mencionada cofradía de los pelaires "tiene muchos privilegios, statutos, usos et costumbres, atorgados por los reyes de Aragon antipasados, et confirmados por el rey don Fernando gloriosament regnant". Que el sistema de elección de su junta directiva compuesta por doce personas consistía en que los mayordomos antiguos selec-

\footnotetext{
${ }^{39}$ Ibídem, docs. 190, 192 y 196.

${ }^{40}$ Ibídem, doc. 203.

${ }^{41}$ Ibídem, docs. 245, 246, 255 y 256.

${ }^{42}$ Ibídem, doc. 250.
} 
cionaban a seis personas, tres de la tierra (de dentro del muro de la ciudad) y otras tres extranjeras (de fuera del muro). Y éstas a su vez elegían por su parte a otras seis personas más, a saber, dos mayordomos nuevos, dos consejeros y dos veedores repartidos al cincuenta por ciento entre los de fuera y los de dentro. Y al respecto se apunta que "de vintiseys anyos a esta part" en la cofradía de los pelaires se había venido utilizando este sistema de insaculación ${ }^{43}$. Lo que demuestra cómo la acción política de la cofradía superaba ampliamente los muros de la ciudad y pretendía extender su influencia sobre el artesanado rural disperso que trabajaba clandestinamente en el término del concejo.

\section{NOTICIAS INÉDITAS PROCEDENTES DE LA DOCUMENTACIÓN MUNICIPAL Y NOTARIAL}

Algún documento notarial de principios del siglo XV ya ha ilustrado no sólo la primacía en cantidad y calidad que adquirió la pañería zaragozana en Aragón, sino también el fenómeno de la creación de compañías para producir tejidos, formadas conjuntamente por mercaderes que ponían el capital y artesanos que aportaban su trabajo a cuenta ajena, en beneficio de dichos comerciantes. En 1401, el notario Juan Blasco de Azuara recoge la constitución de una compañía para explotar un modesto negocio de tinte entre un hombre de negocios, Pedro Olzina, vecino de Zaragoza, que dispone de una tienda propia, y los artesanos tintoreros Juan Brún y Pedro de Moya, habitantes también de la capital ${ }^{44}$.

Los libros del concejo de Zaragoza conservados en el Archivo Municipal son todos del siglo XV: pregones desde 1409, actas a partir de 1439 y contratos de 1448 en adelante. La serie más importante a efectos de obtener la narración oficial de los acontecimientos que tuvieron lugar en la capital es la de los libros de actas. Aquí se han revisado exhaustivamente por dos motivos. Primero, para conseguir los nombres de los veedores o mayordomos que representaban a pelaires, tejedores y tintoreros ante el concejo e introducirlos en la base de datos que ha permitido confeccionar el censo prosopográfico del apéndice. En segundo lugar, para rescatar cualquier noticia sobre los oficios de la lana al margen de las ordenanzas ya conocidas y publicadas, las cuales por otra parte se plasmaban en los libros de contratos y pregones. Ambas estrategias de investigación no habían sido aplicadas hasta el día de hoy. Los resultados son los que se comentan a renglón seguido.

El primer tipo de noticias localizadas en las actas municipales desde 1439 lo constituyen los juramentos de veedores, que suelen responder al

\footnotetext{
${ }^{43}$ Como se verá más adelante, los libros de actas municipales ya recogen dicho sistema electoral desde 1472 , véase nota 55 infra.

${ }^{44}$ J.Á. SESMA MuÑö, Rasgos precapitalistas en la organización industrial aragonesa (siglo XV) en "Medievalia", 10 (1992), pp. 387-402.
} 
siguiente ritual según ilustra el caso de los tejedores el 9 de diciembre de 1439:

Eadem die, en presencia de los muyt honorables don Gonçalvo de la Cavalleria, don Pero Soriano, don Nicolau Çorita, don Bartholomeu Segura, don Bertran d'Urrea, don Antho d'Angusolis, don Bernat Soriano et don Anthon de Gurrea, jurados, parecio Domingo Marlas como mayordomo siquiere veyedor del anyo present del officio de los texidores de la dita ciudat, el qual presento en veyedores del dito officio por al anyo primero vinient a Bartholomeu de Loscos et Johan Aznarez, texidores, los quales juroron en poder del dito don Gonçalvo de la Cavalleria, jurado, sobre la cruz et santos quatro evangelios antellos puestos et por ellos et cadauno dellos manualment toquados et bien et lealment haver et en el dito officio et servar las ordinaciones de aquel" ${ }^{\prime 4}$.

La reseña de este procedimiento ha dejado identificar hasta 21 pelaires, 19 tejedores y 9 tintoreros, es decir, unas cincuenta personas en total. Cuestión clave para lograr un primer esbozo del círculo de individuos que formaban las elites politicas del artesanado lanero zaragozano, teniendo en cuenta que representan una minoria en nuestro censo, en concreto, casi el 21 por ciento de las 234 personas integrantes del mismo.

De algunos de esos veedores se poseen datos importantes gracias a la documentación notarial coetánea. Por ejemplo, un codicilo del año 1475 perteneciente al pelaire Alfonso de Soria ${ }^{46}$, veedor de su oficio cuatro años antes en 1471, retrata con detalle el perfil familiar y la capacidad económica del artesano. Estando enfermo de grave enfermedad de la cual dudaba morir eligió su sepultura en el convento de franciscanos donde estaban enterrados sus antecesores, destinando 500 sueldos para el funeral, novena y aniversario que se celebraría en la iglesia parroquial de San Gil a cuyos pobres vergonzantes se les entregarían 50 sueldos de esa cantidad y, en concreto, otros 100 sueldos de la misma a su hermanastro Martín Sanz por ser persona necesitada. El resto de los 500 sueldos serían distribuidos en los gastos del funeral a criterio de sus albaceas. A su hija Isabel, esposa del honorable Miguel de Casafranca, especiero, le legaba los 500 sueldos que su marido, el citado Casafranca, le debía por ciertos empeños. Pero con esa cantidad, cuando su hija la cobrase de su marido, quería que comprara una heredad que fuese puesta a nombre de la misma, y que en el caso de que ella falleciese pasaría a sus hijos o si no a sus hermanos. Alfonso de Soria estaba casado con Isabel Just y de dicho matrimonio existían seis hijos, es decir, la mayor, la citada Isabel, y sus hermanos Juan, Antonio, Jaimico, Mateico y Violancica. Sólo Isabel y Juan eran mayores de edad, los otros cuatro eran menores y quedarían bajo la tutela de su madre, de su hermano Juan y de su tío paterno, el también pelaire Francisco de Soria, veedor del oficio, lugarteniente del alcaide de Alfajarín y señor del molino

\footnotetext{
${ }^{45}$ AMZ, Concejo, Libros de Actas, 1 (1439-1440).

${ }^{46}$ Archivo Histórico de Protocolos de Zaragoza (en adelante AHPZ), notario Miguel Navarro, hijo, años 1464-1472.
} 
trapero de Almargen, documentado entre 1459 y 1491 . El valor de la herencia de Alfonso de Soria en 1475 superaba los 11.000 sueldos repartidos de la siguiente manera. Para empezar ya se han expresado los 500 destinados a su entierro y los 500 que le legaba a su hija mayor Isabel. Su hijo Juan, cotutor de sus cuatro hermanos menores, recibiría un huerto situado en la partida de Rabal y un campo en la partida de la Hierba, ambas en término de Zaragoza, aparte de 2.000 sueldos que se le darían cuando tuviera edad de casarse y se casara. A cada uno de los cuatro hijos menores se le reservaban igualmente 2.000 sueldos para su matrimonio y si algunos de ellos moría su dotación pasaría a repartirse entre sus hermanos. Los albaceas eran igualmente su mujer, su hijo Juan y su hermano Francisco de Soria.

Entre la clientela del notario Juan de Longares ${ }^{47}$ se han localizado también las últimas voluntades de algunos artesanos del censo prosopográfico que se adjunta como apéndice en el presente artículo. Del 22 de enero de 1438 es un codicilo de María Pascual, segunda esposa del pelaire García el Peco, propietaria de diversas parcelas de tierra que repartió entre seis hijos que tuvo con sus tres maridos. Un codicilo de su tercer esposo, el citado García el Peco, consta en este mismo notario con fecha 20 de septiembre de 1454. Recordemos que este pelaire García el Peco está localizado en el censo tiempo después durante 1459-1460. Del 18 de septiembre de 1443 es otro codicilo del pelaire Pedro Torralba, veedor que fue de su oficio en 1439. Casado con María López y padre de Juan, expresó el deseo de ser enterrado en una sepultura que había comprado en cierta capilla del claustro de la iglesia de Santa Engracia de Zaragoza. El pelaire Juan Gómez, consejero de su oficio hacia 1460, elegía sepultura el 12 de mayo de 1461 en la iglesia del monasterio de Nuestra Señora de la Merced y San Lázaro donde estaba enterrado su padre. Por último, un codicilo del tintorero Juan de la Raz, fechado el 15 de abril de 1453, expresa también que su sepultura había sido comprada en la capilla de Santa Lucía en la iglesia de San Lázaro. Este breve muestrario de clientes del notario Juan de Longares desvela un ambiente de productores autónomos acomodados, propietarios de tierras y de medios de producción al estilo del antes citado Alfonso de Soria.

Quiero destacar que en algunas ocasiones hasta aparecen individuos bajo la denominación simultánea de pelaires y escuderos, lo que subraya la esfera de ciudadanía honrada en la que se veían envueltos. Por ejemplo, en el censo del apéndice aparece el caso de Martín de Pompién, pelaire y escudero, que en 1477 se enfrentó en pleito con la cofradía de su oficio. Dos años después mantenía otros litigios en las cortes del zalmedina y del justicia de Aragón contra el judío Mosse Morfayín, alias Terranero, según un arbitraje ante notario fechado el 11 de junio de $1479^{48}$. El 31 de diciembre

${ }^{47}$ AHPZ, notario Juan de Longares, signaturas 3207 (año 1438), 3213 (año 1443), 3232 (año 1453), 3233 (año 1454) y 3246 (año 1461).

${ }^{48}$ AHPZ, notario Jaime Oliván, 1479, ff. 111r-112v. 
de este mismo año era el honorable Martín de San Juan, escudero y pelaire, quien alquilaba un palacio o granero situado en la calle de las Armas, parroquia de San Pablo, a otro pelaire de nombre Antón Vicent ${ }^{49}$. Ninguno de los dos está recogido en el censo del apéndice. Tampoco figura en el mismo el pelaire Francisco Camañas pero sí su difunto padre, el honorable Luis de Camañas, escudero y pelaire. Francisco firmó ante notario sus capítulos matrimoniales el 31 de junio de $1480^{50}$, acompañado de su madre, la viuda María Martínez. Se casaba con Margarita Gualdarás, hija del honrado don Bernat de Gualdarás, otro escudero pelaire, y de su esposa Pascuala Lázaro. La novia aportaba al matrimonio un malluelo franco sito en Miralbueno, 1.000 sueldos y una cameña de ropa, y el novio 700 sueldos, lanas y arreos de su oficio, una viña y un campo contiguo de tres cahices en la partida de las Fuentes de la Huerva, término de Zaragoza. Como puede observarse, las propiedades rústicas constituían el elemento patrimonial básico a partir del cual se construían estas familias de artesanos acomodados. La materia prima y los utensilios de la profesión daban la identidad urbana a sus poseedores y la posibilidad de enriquecerse con un negocio manufacturero en expansión en la ciudad. En esas circunstancias, se hacía factible su incorporación a la nobleza urbana, los escuderos, aunque existiría la posibilidad de que formaran parte de ella antes de dedicarse al negocio, lo que nos llevaría a un fenómeno de significado distinto. Sea como fuere, en general ése era el nivel de fortuna y prestigio social que envolvía igualmente a diversas familias de escuderos, mercaderes y notarios. Por eso no es de extrañar que los hijos e hijas de los pelaires contrajesen matrimonio entre ellos o con los descendientes de otros burgueses. En ese contexto la endogamía era una estrategia fundamental. Las familias recrecían sus posiciones creando redes de alianzas dentro y fuera del oficio.

El segundo tipo de noticias obtenidas en los libros de actas del Archivo Municipal de Zaragoza ofrece un muestrario dispar de circunstancias entre las que predominan las denuncias de los veedores por falsos tejidos confiscados a determinadas personas en incumplimiento de las ordenanzas vigentes. Siguiendo un orden cronológico la primera de ellas se fecha el 4 de mayo de 1440 cuando los veedores de los pelaires requirieron a los jurados para que entregasen a los veedores del oficio de tintoreros dos piezas de cadines que decían ser falsas. Los tintoreros deberían verlas y reconocerlas y emitir un informe sobre las mismas. Los jurados mandaron al ayudante del andador con las piezas y éste se las entregó a los diputados tintoreros $^{51}$. El desenlace de este asunto se desconoce puesto que no hay más referencias al mismo. Sólo la instancia de los pelaires a los jurados hizo que constase dicho suceso, cuando lo habitual era que los veedores estuvie-

\footnotetext{
${ }^{49} \mathrm{AHPZ}$, notario Juan Barrachina, 1479, f. 6v.

${ }^{50} \mathrm{AHPZ}$, notario Juan Barrachina, 1480, ff. 257r-259r.

${ }^{51} \mathrm{AMZ}$, Concejo, Libros de Actas, 1 (1439-1440).
} 
sen facultados para actuar autónomamente en este tipo de denuncias sin precisar de la mediación de las autoridades.

Una situación similar a la anterior se produjo el 14 de mayo de 1442 cuando un escai blanco que Nicolau del Fayo había recibido de los veedores de los pelaires, el cual se decía que había sido robado, fue librado a un tal Montesino Pertusa ${ }^{52}$. Parece deducirse de esta información que los pelaires habían confiscado al tal Pertusa dicho retal tal vez con la denuncia de ir en contra de sus ordenanzas, y el citado personaje recurrió a los jurados acusando a los pelaires de robo, de manera que tuvieron que devolver a Nicolau del Fayo la pieza y éste se la restituyó a Pertusa por orden de los jurados.

En algunos casos los jurados debían actuar como árbitros para solucionar conflictos de intereses que habían requerido el juicio paralelo de dos oficios. Por ejemplo, el 18 de octubre de $1442^{53}$, los jurados habían visto una sentencia del mayordomo de los mercaderes sobre dos piezas de cadines de Valencia. Domingo Coscollán se las había comprado por 8 libras cada una a Jaime Vidal, pero no acabándose de fiar de la calidad de las mismas, se las mostró a los veedores de los pelaires, quienes emitieron un informe considerando que una era "buena et mercadera" pero que la otra "por quanto era scabeçada que no era mercadera". Coscollán reclamó a Vidal el dinero de la tela mala y apeló en "cort de mercaderes". El mercader mayordomo ordenó que Vidal devolviese el dinero a Coscollán y éste le entregase las dos piezas. Pero Vidal apeló por su parte a los jurados, los cuales consideraron que el mayordomo de los mercaderes había actuado en parte incorrectamente, de manera que la compra efectuada por la tela buena debía confirmarse, así que Coscollán tuvo que pagar las 8 libras de la misma a Vidal y quedarse con ella, debiendo cubrir también la mitad de los costes del juicio de la corte de mercaderes y la totalidad del de los jurados. Ambas partes aceptaron la sentencia como justa.

En otros casos parece que el acusado dilataba el cumplimiento de su pena, como parece dedudirse de una noticia reflejada en los libros de actas el 26 de noviembre de 1471, cuando Alfonso de Soria, el veedor del oficio de los pelaires de Zaragoza cuyo caso anteriormente se ha analizado, informó sobre cuatro paños que había encontrado en casa de Ramón Cruillas hacía ocho meses más o menos, y que según las ordenanzas de su oficio eran inferiores a las medidas permitidas por lo que había sido castigado el tal Cruillas con una multa de 80 sueldos $^{54}$. Todas estas informaciones plasman los problemas que suscitaba la puesta en práctica efectiva del contenido normativo de las ordenanzas de los oficios, que siempre deben interpretarse como expectativas y pretensiones teóricas de monopolio más que

\footnotetext{
${ }^{52}$ AMZ, Concejo, Libro de Actas, 2 (1442).

${ }^{53}$ Ibidem. El 9 de diciembre de ese mismo año, los jurados requerían a los veedores del oficio de la trapería para que reconociesen un un tejido de grana acusado de no ser mercadero que había sido vendido por el comerciante Francés Villarraga al calcetero Esteban Castro.

${ }^{54} \mathrm{AMZ}$, Concejo, Libro de Actas, 5 (1470-1471).
} 
como logros inmediatos y efectivos sobre la realidad económica local. Eran declaraciones de intenciones y ambiciones del artesanado corporativo aferrado a sus tradiciones y prebendas. La dinámica económica era difícilmente previsible y domeñable.

El 25 de marzo de 1490 se reseña también una pronunciación de los pelaires tocante a la controversia existente entre éstos y Mosse Jamorro, judío rebolero de Zaragoza, sobre las multas que los artesanos le demandaban por la venta de 35 arrobas de lana, consistentes en una pena de 5 sueldos por cada arroba ${ }^{55}$. El comerciante judío había exhibido delante de los jurados el privilegio real de 1442 que recogía las ordenanzas de los pelaires con un capítulo dedicado precisamente a "las taras que se han de fazer en las lanas de rebol e de tisora o las tenyidas que por qualesquiere revolero o revoleros, mercader o mercaderes de la dita ciudat, se vendra". Al respecto, los pelaires entendían que nadie podía vender lana con la piel y si lo hacía incurriría en la multa correspondiente. El tal Jamorro lo había hecho y por tanto debía pagar 165 sueldos, es decir, 5 sueldos por cada una de las 35 arrobas, tal y como estipulaba dicha ordenanza.

Incluso, las actas municipales podían suponer la reforma de las ordenanzas vigentes que ya hemos comentado con anterioridad ${ }^{56}$. El 8 de junio de 1472 la cofradía de tejedores expuso a los jurados que entre sus miembros había habido algunas diferencias a la hora de proceder a la elección anual de mayordomos y veedores "por part de los de dentro de la ciudat como de los de la poblacion de aquella" ${ }^{57}$. Algunas personas habían logrado que se alcanzase un pacto para "sosiego e reposso de todos los del dito officio" por el cual se debían hacer dos bolsas para insacular los dos mayordomos, a saber, "una los de dentro de la ciudat et en la otra los de la poblacion". Y otras dos bolsas de idéntica manera para la extracción de los nombres de los dos veedores, de manera que el bando de dentro tuviese un veedor y un mayordomo cada año, y el bando de fuera lo mismo. Y tras el año de mandato pasaran a ocupar de forma alternativa los cargos de mayordomo y veedor hasta dejar su vacante en la junta a los tres años: "E ayan a vaquar en aquel officio que sallido hauran por tiempo de tres anyos e de hun officio a otro, es a saber, de mayordomo a veyedor o de veyedor a mayordomo hun anyo".

En otro orden de cosas, los problemas derivados de las infraestructuras industriales centran la atención de los jurados en diversos momentos. Entre 1469 y 1479 la cofradía de los pelaires se enfrentaba a los señores de varios molinos de la partida de Almargen por el uso de la acequia mayor de Urdán que abastecía también al molino trapero de la cofradía ${ }^{58}$. En 1490 hubo otro pleito que enfrentó a Dionís de Coscón, señor del molino harine-

\footnotetext{
${ }^{55}$ AMZ, Concejo, Libro de Actas, 9 (1489-1490).

${ }^{56}$ Véase nota 42 supra.

${ }^{57}$ AMZ, Concejo, Libro de Actas, 6 (1471-1472). Los de la población habitaban entre las dos murallas de la ciudad.

${ }^{58}$ AMZ, Concejo, Libro de Actas, 4 (1468-1469), 25 de julio y 13 de octubre de 1469
} 
ro llamado de Almargén, edificado en la acequia de Urdán del río Gállego contra el pelaire Francisco de Soria, señor del molino trapero situado también allí y denominado igualmente de Almargén, apoyado por la cofradía de los pelaires. Desde antiguo el agua de la acequía se la repartían por la mitad ambos molinos, de manera que los jurados conminaban a las partes a seguir respetando esa costumbre sin que ni unos ni otros pudieran hacer paradas ni traviesas en dicha acequia sin permiso municipa ${ }^{59}$.

Con los tintes también había conflictos que llegaban a los jurados, como por ejemplo, el 9 de diciembre de 1471 entre maestre Francisco Martín, médico, de una parte, y los tintoreros y señores de los huertos y heredades cercanos a los tintes de la ciudad de Zaragoza ubicados en la partida de Santa María de Altabás, de la otra ${ }^{60}$. El conflicto había surgido porque el citado médico quería construir un tinte nuevo y para ello iba a obrar en un huerto ubicado en la mencionada partida de Altabás. Los tintoreros esperaban que les causase grandes daños por cuanto quedaría enclavado en el curso de la acequía antes que todos los otros tintes, de manera que las aguas que de allí saliesen iban a perjudicar sus heredades hasta la perdición total de las mismas.

A modo de colofón, otra noticia municipal alude a la participación activa del artesanado en la fiesta del Corpus Christi con pequeñas representaciones teatrales. El 16 de mayo de 1442, los jurados zaragozanos instaban a los mayordomos de los pelaires a que respondiesen a sus ruegos para que su cofradía realizase "qualque entremes notable el dia et fiesta de Corpore Christi primo vinient por honor et reverencia de la dita fiesta". Pero los mayordomos contestaron que habían hecho reunirse al capítulo de la cofradía y que habían deliberado enviar diez pares de "brandones" o antorchas para que acompañasen la procesión "et que de present otro entremes no podian fazer porque las gentes que tenian los perayres eran engueradas por las ordenes et monasterios de la dita ciudat, los quales fazian entremeses el dito dia" $"$.

\section{VALORACIÓN DE LAS DIMENSIONES DE LA INDUSTRIA SEDERA}

No existen ordenanzas de los oficios de la seda para la Zaragoza del siglo XV. Los primeros textos que publicó el profesor Ángel San Vicente Pino se fechan bien entrado el siglo XVI ${ }^{62}$. De su lectura, sin embargo, se deducen algunas cuestiones en retrospectiva. El 23 de julio de 1537

\footnotetext{
${ }^{59} \mathrm{AMZ}$, Concejo, Libro de Actas, 9 (1489-1490), ff. 148v-149v (2 de diciembre de 1490).

${ }^{60} \mathrm{AMZ}$, Concejo, Libro de Actas, 5 (1470-1471).

${ }^{61} \mathrm{AMZ}$, Concejo, Libros de Actas, 2 (1442).

${ }^{62}$ Á. SAN VICENTE PINO, Instrumentos para una historia social y económica del trabajo en Zaragoza en los siglos XV a XVIII, 2 vols., Zaragoza, Real Sociedad Económica Aragonesa de Amigos del País, 1988.
} 
el concejo de Zaragoza aprobó ordenanzas para el oficio de tireteros de la ciudad haciendo constar que "alguno del dicho offitio de tireteros no pueda poner cabos en tiretas de seda ni esfiladiz de seda ni cuero sino que sean clavadas y limadas delante y detras de los cavos" ${ }^{33}$. Los tireteros trabajaban pues con seda y en el fogaje realizado en la ciudad en 1496 hasta cinco contribuyentes declararon ser tireteros: maestre Antón, Martín de Araso y Juan, los tres en la parroquia de Santa María del Pilar; Domingo en la de San Gil y maestre Guallart en San Felipe ${ }^{64}$.

Asimismo, en 1549 el oficio de cordoneros logró que los sombrereros "no puedan hazer para vender cordones, franjas ni ninguna manera de guarniciones de seda ni filadiz de seda, sino tan solament para los sombreros que hazen y venden en su casa y no para vender los dichos cordones, franjas, flocos y guarniciones a solas" ${ }^{65}$. En esta ocasión el fogaje de 1496 ya deja identificar a 14 boneteros o sombrereros localizados en su mayor parte en la parroquia de Santa María del Pilar, alguno que otro con apellido sospechosamente extranjero como un tal Juan de Brujas. Los oficios de cordoneros, parcheros y sombrereros se confirma que utilizaban habitualmente seda en sus productos y que por ello interferían unos con otros en competencia técnica allá por los años 1567 y $1578^{66}$. Por añadidura, hasta 1569 no se fundó una cofradía de velluteros y tafetaneros bajo la advocación de san Jerónimo, aunque desde finales del siglo XV existían personas que practicaban dichos oficios. En 1617 dichos oficios de velluteros y tafetaneros se unieron con el de veleros en una única cofradía ${ }^{67}$.

También desde 1526 se documenta en Zaragoza la formación de compañías entre mercaderes y artesanos para la cría de gusanos de seda con hojas de morera ${ }^{68}$. El 22 de marzo de 1560 el guantero Juan de Subiro firmaba una comanda con un torcedor de seda posiblemente italiano llamado Claudio Gordoni por la cual le entregaría cuatro onzas y media de simiente para cultivar gusanos con la hoja de setenta y tres moreras que había junto a una casa suya, en el interior de la cual serían criados los capullos de seda en lechos de hojas alojados en cañizos o estanterías ${ }^{69}$. En 1570, don Ramón Cerdán, señor de Usón, y el hilador de seda Melchor Ribera también se asociaron para la cría de gusanos de seda empleando la cosecha de hojas de moreras de las heredades y huertos del término de Villamayor y las diversas casas con cañizos y estanterías que había en dicha población. Además el

\footnotetext{
${ }^{63}$ Ibídem, tomo I, doc. 98, p. 169.

${ }^{64}$ Serrano, La población de Aragón, citado.

${ }^{65}$ SAN VICENTE, Instrumentos, citado, tomo I, doc. 125, p. 221. Véase sobre los sombrereros o boneteros de la ciudad el artículo de M.I. FALCÓN PÉREZ, El gremio de boneteros zaragozanos a fines de la Edad Media "Homenaje al Profesor Juan Torres Fontes", Universidad de Murcia, 1987, vol. I, pp. 465-476.

${ }^{66} \mathrm{Ibídem}$, tomo I, doc. $188,190,245$ y 247 , pp. 356-359, 361-362, 434-435 у 436 respectivamente.

${ }^{67}$ ÁGREDA, Los ornamentos de las iglesias, citado, p. 166.

${ }^{68}$ Ibídem, p. 120.

${ }^{69}$ SAN VICENTE, Instrumentos, citado, tomo I, doc. 161, p. 309.
} 
hilador se obligaba a que las moreras "esten bien podadas al modo de Valencia a conoscimiento de dos personas praticas puestas por cada una de dichas partes" ${ }^{\prime 7}$. Entre 1573 y 1576 el infanzón Jerónimo Ferrer compró en Zaragoza unos ochenta cañizos y estableció una "casa de la seda" que funcionaba con mano de obra femenina de la cual se conocen algunos contratos de mozas ${ }^{71}$.

Es muy significativo el hecho de que hasta el 13 de julio de $1513^{72}$ no se fundase una cofradía de tejedores de seda y algodón en Zaragoza bajo la advocación de Nuestra Señora de la Esperanza. Por mucho que los usantes en el oficio hubiesen aumentado y se considerara oportuno promulgar ordenanzas para evitar fraudes todo parece confirmar que el negocio de la seda consistía antes que nada, como ahora se verá, en la importación de tejidos de seda valencianos por parte de algunos mercaderes zaragozanos. En realidad, los promotores de la cofradía sólo eran cuatro personas cuyos nombres son Cristóbal de Frías, Antón de Laínez, Juan Pastriz y Juan Romero, vecinos de la ciudad. En Valencia la cofradía de tejedores de seda también estaba bajo la advocación de la Esperanza desde 1465. Por su parte, la cofradía de los velluteros valencianos tenía como patrón a san Jerónimo desde 1477, como sucederá después con la cofradía de los velluteros de Zaragoza avanzado ya el siglo XVI. ¿Es una coincidencia o se imitó conscientemente a Valencia en la elección de los patrones? ¿Si así fue qué se quería demostrar haciéndolo? Por desgracia, los capítulos concretos de las primeras ordenanzas zaragozanas no han llegado hasta nosotros. Fueron insertos en un libro de contratos, el de ese año 1513, que casualmente no se conserva en el Archivo Municipal. Quizás hubiesen aclarado algo este asunto de las devociones religiosas, que no es un tema baladí.

Antes de 1500 los libros de actas del concejo son absolutamente silenciosos respecto al negocio sedero. El 5 de marzo de 1490 se reseña una carta de franqueza otorgada a Juan de Ovillos, velero habitante en Zaragoza $^{73}$. Otro velero de nombre Juan Cortés habitaba en la parroquia de San Felipe en 1496 según el fogaje realizado en la ciudad. Sin embargo, el estudio prosopográfico realizado por Cristina Sebastián ${ }^{74}$ demuestra que existió como mínimo una docena de veleros y tejedores de seda activos en la ciudad de Zaragoza a finales del siglo XV: el judío Samuel Adret, alias Aviayu (1486-1491), Antonio de Altanás (1493), Juan de Avilés (1485), el judío Zetri Behor (1485), Galcerán Belenguer (1477), Juan Calvarrón (1486), Pedro Climent (1485), Miguel Garens (1486), Jaime Lençol

\footnotetext{
${ }^{70}$ Ibídem, tomo I, doc. 198, pp. 372-373. Véase sobre la industria sedera de Valencia el libro de NAVARRO, Los origenes de la sedería valenciana (siglos $X V-X V I)$, citado.

${ }^{71}$ ÁGREDA, Los ornamentos de las iglesias, citado, p. 118.

${ }^{72} \mathrm{AMZ}$, Libros de Actas, 16 (1512-1513).

${ }^{73}$ AMZ, Libros de Actas, 9 (1489-1490).

${ }^{74}$ C. SEBASTIÁN FrAnCO, El negocio de la seda en Zaragoza (siglos XV-XVI), trabajo de investigación inédito para la obtención del Diploma de Estudios Avanzados del programa de doctorado del Departamento de Historia Medieval de la Universidad de Zaragoza, curso 20042005, dirigido por el profesor Germán Navarro Espinach.
} 
(1466), Antón Mateu (1473), Juan Ram (1486), Miguel de Suñén (1498) y Miguel Talamanca (1485). Con todo, no hay que despreciar el hecho de que estos artesanos u otros que por ahora desconocemos acostumbrasen a vivir de manera itinerante entre los principales centros industriales de la Corona de Aragón. Al respecto, es curioso el ejemplo que desvelan las actas municipales de Zaragoza el 24 de octubre de 1492 con el desavecindamiento de Fernando Ruiz, tejedor de seda "vezino e habitador que solia ser de la present ciudat y de present vezino e habitador de la ciudat de Valencia, el qual dixo que su intencion era de vivir en la dicha ciudat de Valencia e assi que se desvezinaba e desvezino de la dicha ciudat"75. En el censo prosopográfico de mi tesis doctoral consta un tal Fernando Ruiz, velero de Zaragoza, que fue consejero municipal de su oficio en la ciudad de Valencia en 1510, pagó 15 sueldos en la tacha real de 1513 como habitante de la misma y se avecindó finalmente el 2 de octubre de 1515 en la calle de la Xerea, parroquia de San Esteban, presentando una carta de desavecindamiento del concejo de Zaragoza fechada a 22 de marzo de $1515^{76}$. Todo parece sugerir que se trata de la misma persona puesto que de lo contrario sería mucha casualidad.

Tal vez Fernando Ruiz optó por marcharse a una ciudad con mayor prosperidad en el negocio sedero como era la Valencia de aquel entonces. Desde luego esta situación trae a colación la historia de otro sedero valenciano, Francisco Natera, que huyó a Aviñón perseguido por la Inquisición y que, según las declaraciones de diversos testigos del proceso, estaba pensando en marcharse a dicha ciudad francesa desde hacía meses, puesto que un nieto suyo que vivía allí le había escrito comentándole que el negocio de la seda iba en auge y resultaba más rentable que en Zaragoza.

Los datos que ofrece ese proceso inquisitorial contra Francisco Natera $^{77}$ sobre el negocio de la seda en la Zaragoza anterior al siglo XVI merecen pues toda nuestra atención una vez más. Natera y sus cuñados Pedro Tristán y Gaspar Redó, sederos conversos oriundos de Gandia que ya habían sido procesados por el tribunal valenciano de la Inquisición por prácticas judaizantes, se llevaron de Zaragoza en 1500 algunos bienes y mercancías del comerciante mudéjar Yusuf Xama ${ }^{78}$, tras ser apresado éste por la Inquisición. Uno de los testigos declarantes en el proceso, Francisco de Porras, tejedor de terciopelo habitante en Zaragoza, dijo que Natera era factor o menestral del torno de seda propiedad de Xama, el cual acostum-

\footnotetext{
${ }^{75}$ AMZ, Libros de Actas, 11 (1491-1492).

${ }^{76} \mathrm{G}$. NAVARRO ESPINACH, Industria y artesanado en Valencia, 1450-1525. Las manufacturas de seda, lino, cáñamo y algodón, 4 vols., tesis doctoral en microficha, Universidad de Valencia 1995 , tomo III, pp. 1079-1080. Sobre la emigración aragonesa a Valencia véase también NAVARro, Politica municipal y avecindamientos, citado.

${ }^{77}$ Archivo Histórico Provincial de Zaragoza, Sección Archivos Judiciales, Tribunal de la Inquisición de Aragón, sig. 19, dọc. 4, 14 folios, transcripción publicada en NAVARRO, Los musulmanes y la ruta de la seda, citado, pp. 310-324.

${ }^{78}$ Véase el reciente estudio de J. ABELLA SAMITIER, Una familia de mudéjares aragoneses en el tránsito de la Edad Media a la Moderna: los Xama de Zaragoza, "En la España Medieval", 28 (2005), pp. 197-212.
} 
braba a entregarle madejas de seda a cambio de tejerle piezas de terciopelo con esa materia prima. Este mismo testigo declaró que, unos días antes, había estado confeccionando diversas varas de terciopelo en un telar que el mismo Natera le vendió a cambio de saldar una deuda. Por añadidura, otros testimonios harán constar algunos útiles de Xama que Natera también les había vendido y subastado, por ejemplo, una caldera grande para hervir los capullos, un cepillo de plegar seda, o un mortero grande de cobre que era del dicho torno.

$\mathrm{Al}$ parecer Francisco Natera con este robo quiso cobrarse unas cantidades que le debía Yusuf Xama, para el cual trabajaba como maestro de un torno de seda, teniendo una amplia experiencia en el sector, ya que hay constancia de que por lo menos desde el año 1481 dicho converso trabajaba en Valencia como sedero ${ }^{79}$. Además la mención que se hace de Natera como "mercator civitatis Valentie" en unos documentos realizados ante notario una semana antes de su fuga de Zaragoza ${ }^{80}$, hace pensar que era una persona que no sólo trabajaba, sino que también comerciaba seda, y no un simple artesano contratado por Xama esporádicamente. Varios testimonios explicaron además que Natera era quien entraba en contacto con ellos para suministrarles madejas de seda con las que ellos confeccionaban tejidos, en otra muestra más de trabajo a destajo mediante el encargo a domicilio. La función del sedero era pues coordinar y controlar el ciclo productivo, entregando materias primas sin elaborar o semielaboradas.

El sedero valenciano Francisco Natera, que fue denunciado un día después de abandonar la ciudad de Zaragoza por el padre de su amante, llevaba trece o catorce meses de relación con Inés Pérez de Novillas, hasta tal punto que esta mujer se trasladó a vivir con él, junto a la hermana de Natera y sus dos hijas, una de las cuales, Gracia, estaba casada con Gaspar Redó, otro sedero converso proveniente de Valencia, procesado asimismo por la Inquisición ${ }^{81}$. De esta manera se conformó una compleja estructura familiar, donde Natera era cabeza de un grupo formado por su amiga Inés y su hermana viuda Violante Natera junto con las hijas de ésta, llegando a exigirles a todas estas mujeres un juramento por el que se comprometían a acompañarle en su fuga de Zaragoza. Quizás el padre de Inés, Juan Pérez de Novillas, no estaba contento con la relación que tenía su hija con Natera y el deseo de recuperarla hizo que le denunciase ante el Santo Oficio, consiguiendo parcialmente su objetivo, al refugiarse las mujeres en su casa ante la huida de aquél.

El día 12 de octubre de 1500 los fugitivos fueron detenidos en Navarra y puestos a disposición del tribunal de Zaragoza, cuyo juez y comisa-

\footnotetext{
${ }^{79}$ Véase el estudio prosopográfico del tomo III de la tesis doctoral de NAVARRO, Industria y artesanado en Valencia, citado.

${ }^{80} \mathrm{AHPZ}$, notario Juan de Altarriba, año 1500, ff. 203-204.

${ }^{81} \mathrm{El}$ listado de procesados por la Inquisición en Valencia fue publicado por R. GARCíA CÁRCEL, Orígenes de la Inquisición Española. El tribunal de Valencia, 1478-1530, Barcelona, Península, 1976.
} 
rio Antonio Ros decretó varias sentencias. La hermana de Francisco Natera, Violante, fue condenada a no abandonar la ciudad de Zaragoza, pena que se repitió para la amante del sedero fugado, Inés Pérez de Novillas, y para la sobrina de éste, Gracia Ruiz, que se había casado con Gaspar Redó, otro de los perseguidos por la Inquisición. Precisamente Gaspar Redó consiguió trasladarse a Valencia junto a su esposa y Violante Natera, aunque debiendo presentarse ante los inquisidores de Valencia con una carta del juez Antonio Ros, seguramente para que se controlase allí el comportamiento de estos conversos. Respecto a Francisco Natera recibió la condena de no salir de la ciudad de Zaragoza, pena que el mismísimo Yusuf Xama pidió que fuese levantada en el año 1503.

Queda por exponer una última cuestión clave para valorar el negocio sedero en la Zaragoza anterior a 1500. Se trata del papel de los Ribas en la exportación de tejidos de seda de Valencia a Zaragoza desde por los menos el año 1493. El dato fundamental se refiere a unas cantidades importantes de tejidos de seda que dos mercaderes de Zaragoza declararon exportar hacia su ciudad ante las autoridades valencianas que recaudaban la talla de los paños de la Generalidad. Entre las 40.000 varas registradas en 1512 las partidas de Gaspar de Ribas sumaban la cifra más alta del total de 197 declarantes con 3.640 varas de tejidos de seda de diferentes tipos (terciopelos, satenes, damascos, etc.). Otro comerciante de nombre Jerónimo de Ribas cuyo destino de exportación era Zaragoza ocupó también un puesto relevante en el conjunto de declarantes aunque sólo alcanzaba las $894 \mathrm{va}-$ ras, una cuarta parte de las exportaciones de Gaspar ${ }^{82}$.

¿Quiénes eran Gaspar y Jerónimo de Ribas? La primera noticia que se tiene de uno de ellos corresponde al 11 de febrero de 1493 cuando Gaspar de Ribas, mercader de Zaragoza habitante en Valencia, nombró procuradores generales de sus negocios a sus parientes Fadrique y Bernardo de Ribas $^{83}$. Gaspar no se avecindó en Valencia como tal mercader de Zaragoza hasta el 3 de abril de 1507. Su casa estaba en la calle de mosén Beneito en la parroquia de San Nicolás, y fue el notario Luis Prats quien actuó como fiador suyo en el acto de avecindamiento ${ }^{84}$. Gaspar descendía de Samuel Altordox, judío de Tauste, al igual que todos los Ribas de Zaragoza y Monzón, y tenía un hermano llamado Benegas que era trapero. Parece confirmarse, pues, que Gaspar se marchó de Zaragoza para vivir en Valencia mucho antes de 1500, y allí se casó y murió, dejando hijos e hijas y descendientes ${ }^{85}$.

\footnotetext{
${ }^{82}$ Véase el balance global de los declarantes del manifiesto de las sedas de 1512 en la obra de NAVARRO, Los orígenes de la sedería, citado, apéndice núm. 8, pp. 295-298. Los registros detallados de Gaspar y Jerónimo de Ribas en la tesis doctoral del mismo autor, Industria y artesanado en Valencia, citado, tomo IV, pp. 1375-1381.

${ }^{83}$ Archivo del Reino de Valencia, Protocolos, notario Jaume Salvador, sig. 2010.

${ }^{84}$ Archivo Municipal de Valencia, Llibres d'Aveünaments, b3-9 (1502-1511), f. 150r. Véase NAVARRO, Política municipal y avecindamientos, citado. p. 105 .

${ }_{05}^{85}$ El Libro Verde de Aragón, edición de M. Combescure, Zaragoza, Libros Certeza, 2003,
} 
Fadrique de Ribas, mercader de Zaragoza y procurador general de los negocios de Gaspar en 1493, tampoco se avecindó en Valencia hasta el mismo año que lo hizo Gaspar, esto es, el 23 de noviembre de 1507. Era mercader de Zaragoza y habitaba en una casa de la calle del horno que estaba cerca de la escuela de la Vallada, siendo el notario Luis Prats fiador suyo en el acto de avecindamiento ${ }^{86}$. Fadrique era uno de los hijos de Bernardo de Ribas el Sordo, otro descendiente de Samuel Altordox. En realidad, Fadrique tenía por los menos tres hermanos, uno llamado Bernardo -el que también era procurador de Gaspar-, otro llamado Francisco que era trapero, y un tercero de nombre Paulo que acabó por avecindarse asimismo en Valencia. Fadrique se casó con la hermana de un tal Garçimoya y se instaló en dicha ciudad donde tuvo hijos y nietos ${ }^{87}$. Por su parte, Bernardo de Ribas, hermano de Fadrique y procurador de Gaspar en 1493, aparece en la documentación como mercader residente en la corte del rey Fernando el Católico, casado y con hijos ${ }^{88}$.

Paulo de Ribas, mercader de Zaragoza avecindado en Valencia el 18 de noviembre de 1524, coincide que tenía su domicilio como Gaspar en una casa - no se sabe si en la misma que él- que estaba ubicada en la calle de mosén Beneito en la parroquia de San Nicolás de Valencia, actuando como fiador suyo en el avecindamiento el ciudadano Luis Beltrán ${ }^{89}$. En el Libro Verde de Aragón se dice que Paulo ${ }^{90}$ era hijo de Bernardo de Ribas el Sordo y que tenía dos hermanos, Bernardo y Catalina, pero no se cita ni a Fadrique ni a Francisco, en clara contradicción con lo dicho sobre Fadrique. Lo cierto es que Paulo tenía establecida una compañía para el comercio de paños en 1525 junto con sus socios Juan de León, jurado y ciudadano de Zaragoza, Miguel de Monzón y Gaspar Ortigas, ambos mercaderes. Como socio residente en Valencia Paulo se convertía en el responsable de los tejidos importados desde allí hacia Zaragoza ${ }^{91}$.

Por último, queda hablar de Jerónimo de Ribas, mercader exportador de sedas desde Valencia a Zaragoza en 1512, del cual no se conocen datos familiares a través del Libro Verde de Aragón. Sí que se sabe que los hermanos Francisco y Jerónimo de Ribas, mercaderes de Zaragoza, en los años veinte del siglo XVI aparecen constantemente exportando lana en grandes cantidades a Barcelona, Valencia y los Países Bajos, a la vez que dirigían una compañía para el comercio de paños fundada el 6 de diciembre de 1523. Este tipo de compañías con doble sede en Zaragoza y Valencia ponen de manifiesto que la capital valenciana era uno de los centros princi-

\footnotetext{
${ }^{86}$ Archivo Municipal de Valencia, Llibres d'Aveïnaments, b3-9 (1502-1511), f. 169r. Véase NAVARRo, Política municipal y avecindamientos, citado.

${ }^{87}$ El Libro Verde de Aragón, citado, p. 103.

${ }^{88}$ Ibídem, p. 103.

${ }^{89}$ Archivo Municipal de Valencia, Llibres d'Aveünaments, b3-12 (1524-1526), f. 75r. Véase NAvARro, Política municipal y avecindamientos, citado.

${ }^{90}$ El Libro Verde de Aragón, citado, pp. 100-101.

${ }^{91}$ ÁGREDA, Los ornamentos en las iglesias zaragozanas, citado, pp. 124 (nota 50) y 192.
} 
pales desde los que se importaban tejidos de seda a la capital aragonesa a lo largo del Quinientos ${ }^{92}$.

Con todo, hay que señalar que, aparte de los Ribas, hubo otros artesanos y comerciantes que exportaron tejidos en 1512 hacia Zaragoza como Alonso de Aragón, Guillermo Álvarez, Juan Asensi, Francisco de Ávila, Pedro García, el italiano Luca di Jusserano, Juan Mercader, Juan de Monjelos, Juan Monreano, Juan de Oquendo, Juan Pérez, Miguel Pérez, Mateo Ramírez, Juan Siso, Na Sunyera y Pedro Ximent. Otros comerciantes exportaron tejidos al reino de Aragón en general sin expresar ningún destino concreto en el manifiesto como era el caso del sombrerero Juan Aparici, Juan Asensi, Juan Dolz, Antonio Guardiola, Luis de Guerra, Diego Gutiérrez, Juan de Monjelos, Miguel Pérez y Jaime Ribera. Finalmente, un tercer grupo de comerciantes detalló en sus registros fiscales los destinos aragoneses específicos hacia los que enviaba sus paños de seda, concretamente a Calatayud (Miguel Pérez y Francisco Zaporta), Tarazona (Juan Bernat), y Teruel (el sombrerero Juan Aparici y Juan Pérez) ${ }^{93}$.

Antes de 1500 las exportaciones de sedas valencianas hacia Aragón no eran tan cuantiosas. En 1475 se declararon 21.000 varas en total frente a las 40.000 de 1512. Los tejidos de seda enviados desde la ciudad de Valencia hacia diversos lugares del reino de Aragón son muy escasos. El 18 de enero de 1475 el mercader Rossell Andreu vendió 4 varas y 2 palmos de damasco blanco a la iglesia parroquial de una aldea de Teruel. El día 28 de este mismo mes vendía 6 varas y 3 palmos de damasco blanco para confeccionar una capa para la iglesia parroquial de Ojos Negros. El 6 de marzo sellaba 3 palmos de damasco verde para una iglesia de la ciudad de Teruel. El comerciante Gabriel Barberá vendió 5 varas y 3 palmos de damasco blanco a la iglesia parroquial de Manzanera. Martín Beltrán sacaba del reino valenciano con destino a Aragón 15 varas y 2 palmos de terciopelo negro el 22 de febrero. El 19 de marzo era Francesc Besant quien hacía lo mismo que el anterior con 15 varas y 2 palmos de brocado gris. El día 6 de este último mes, Joan Macip vendió dos partidas de tejidos a la iglesia de Santa María de Teruel consistentes en 14 varas de brocado azul por un lado, y 3 varas y 3 palmos de brocado carmesí por el otro. El 18 de marzo Sancho Navarro sacaba catorce piezas de camelotes de seda hacia Aragón. También el mercader genovés Francisco Palomar sacó para Zaragoza el 28 de noviembre primero 27 varas de terciopelo morado y después en tres piezas otras 75 varas de terciopelo negro. Los herederos del judeoconverso turolense Martín Ruiz declaraban el 14 de febrero hasta 20 paños pintados de seda de Almería con destino a Aragón. Por último, Gisbert de Tolosa sacaba 6 medias telas de camelote de colores para Zaragoza ${ }^{94}$. En definitiva, un volumen pequeño de unas 200 varas para todo Aragón en 1475

\footnotetext{
${ }^{92}$ Desportes, La industria textil en Zaragoza, citado, pp. 54, 97 (nota 187), 99, 106.

${ }^{93}$ Véase sus registros concretos en NAVARRO, Industria y artesanado, citado, tomo IV

${ }^{94}$ Ibídem, pp. 1168, 1169, 1170, 1178, 1182, 1183, 1203, 1220, 1224, 1231 у 1238.
} 
cuando la cantidad total declarada llegaba a las 21.000, exportadas sobre todo a Castilla, como sucederá también en 1512 al tiempo que el caudal de tejidos hacia Aragón alcanzaba en torno a las 5.000 varas.

Fecha de recepción del artículo: marzo 2008

Fecha de aceptación y versión final: mayo 2008. 


\section{CENSO DE ARTESANOS DE LA LANA \\ DE LA CIUDAD DE ZARAGOZA \\ (1439-1496)}

Fuentes contrastadas: Archivo Municipal de Zaragoza, Actos Comunes, 1 (1439-1440), 2 (1442), 3 (1467-1468), 4 (1968-1969), 5 (1470-1471), 6 (1471-1472), 7 (1482), 8 (1489), 9 (1489-1490), 10 (1490-1491), 11 (1491-1492), 11bis (1493-1494) y 12 (1495-1496); M. I. Falcón Pérez, Ordenanzas y otros documentos complementarios relativos a las Corporaciones de oficio en el reino de Aragón en la Edad Media, Zaragoza, 1997, docs. 167, 179, 188, 189, 191, 224 y 250; y A. Serrano Montalvo, La población de Aragón según el fogaje de 1495, 2 vols., Zaragoza, 1997, tomo I, pp. 67-115.

\begin{tabular}{|c|c|c|c|}
\hline Nombre & Oficio & Años & Actividad \\
\hline Abad, Juan & bajador & 1454 & Fundador de la cofradía de su oficio \\
\hline Aceit, Pedro de & tintorero & 1482 & Mayordomo del oficio \\
\hline Adam, Domingo & tejedor & 1458 & Veedor del oficio \\
\hline Agustín, Jaime & pelaire & 1459 & Miembro de la cofradía de su oficio \\
\hline Aínsa, Pascual de & pelaire & 1460 & Asiste a una reunión de la cofradía de su oficio \\
\hline $\begin{array}{l}\text { Alcanadre, Salvador } \\
\text { de }\end{array}$ & pelaire & 1491 & Asiste a una asamblea del oficio \\
\hline Alcañiz & pelaire & 1496 & Casa en la parroquia de San Lorenzo \\
\hline Alfonso, Juan & bajador & $1459-1496$ & $\begin{array}{l}\text { Miembro de la cofradía de pelaires y bajadores. } \\
\text { Casa en la parroquia de San Felipe, citado como } \\
\text { maestre Alonso }\end{array}$ \\
\hline Alfonso, Pedro & tejedor & 1496 & Casa en la parroquia de San Gil \\
\hline Alforge, Pascual de & tejedor & 1442 & Veedor del oficio \\
\hline Algueta, Magín de & pelaire & $1491-1492$ & $\begin{array}{l}\text { Asiste a una asamblea citado como Arriaga. Vee- } \\
\text { dor del oficio }\end{array}$ \\
\hline Almazán, Juan de & tejedor & 1468 & Veedor del oficio \\
\hline Alós, Juan de & pelaire & 1459 & Miembro de la cofradía de su oficio \\
\hline Alpartil, Domingo de & pelaire & $1439-1460$ & $\begin{array}{l}\text { Veedor del oficio. Asistente a una reunión de la } \\
\text { cofradía. }\end{array}$ \\
\hline Alpartil, Pedro de & pelaire & $1460-1468$ & $\begin{array}{l}\text { Asistente a una reunión de la cofradía. Veedor } \\
\text { del oficio }\end{array}$ \\
\hline Amic, Pedro de & pelaire & 1460 & Asistente a una reunión de la cofradía \\
\hline Anziendo, Martín de & pelaire & 1496 & $\begin{array}{l}\text { Dos casas en la calle de la Hilaza, parroquia de } \\
\text { San Pablo }\end{array}$ \\
\hline Ara, Martín de & tejedor & $1442-1458$ & Veedor del oficio. Prohombre del oficio \\
\hline Aranda, Juan de & pelaire & 1496 & Casa en la parroquia de San Lorenzo \\
\hline Arcos, Fernando de & tintorero & 1482 & Veedor del oficio citado como maestre \\
\hline Arcos, Miguel de & pelaire & 1490 & $\begin{array}{l}\text { Licencia de obra para unas casas suyas en la pa- } \\
\text { rroquia de San Jaime }\end{array}$ \\
\hline Ardevín, Antón de & pelaire & 1459 & Miembro de la cofradía de su oficio \\
\hline Arey, Pedro de & pelaire & $1490-1491$ & $\begin{array}{l}\text { Veedor del oficio. Asiste a una asamblea del mis- } \\
\text { mo citado como Pedro de Avani }\end{array}$ \\
\hline Arnau & bajador & 1496 & $\begin{array}{l}\text { Casa en la parroquia de San Gil citado como } \\
\text { maestre }\end{array}$ \\
\hline Arnau & pelaire & 1496 & Casa en la parroquia de la Santa Cruz \\
\hline Artayne,Francisco de & tejedor & 1458 & Prohombre del oficio \\
\hline
\end{tabular}




\begin{tabular}{|c|c|c|c|}
\hline Aviego, Juan de & pelaire & 1491 & Asiste a una asamblea del oficio \\
\hline Aznárez, Juan & tejedor & 1439 & Veedor del oficio \\
\hline $\begin{array}{l}\text { Baus de Barbant, En- } \\
\text { rique }\end{array}$ & bajador & 1454 & Fundador de la cofradía de su oficio \\
\hline Bayo, Gil del & pelaire & $1459-1460$ & $\begin{array}{l}\text { Miembro de la cofradía. Asistente a una reunión } \\
\text { de la misma. Diputado por el oficio para alquilar } \\
\text { el batán de la cofradía a dos pilateros }\end{array}$ \\
\hline Belmont, Martín de & pelaire & 1459 & Miembro de la cofradía de su oficio \\
\hline Benet, Mateo & pelaire & 1496 & $\begin{array}{l}\text { Casa en la parroquia de la Seo. Propietario de un } \\
\text { tinte en la parroquia de Santa María de Altabás }\end{array}$ \\
\hline Berlanga, Martín de & pelaire & $1459-1460$ & $\begin{array}{l}\text { Miembro de la cofradía de su oficio. Asiste a una } \\
\text { reunión de la misma }\end{array}$ \\
\hline Berlanga, Pedro de & pelaire & $1459-1468$ & $\begin{array}{l}\text { Miembro de la cofradía de su oficio. Mayordomo } \\
\text { del oficio. }\end{array}$ \\
\hline Blasco, Fernando & pelaire & $1490-1496$ & $\begin{array}{l}\text { Veedor del oficio. Asiste a una asamblea del mis- } \\
\text { mo. Veedor del oficio }\end{array}$ \\
\hline Bolluz, Galacián de & pelaire & 1491 & $\begin{array}{l}\text { Mayordomo del oficio. Tiene unas casas en la } \\
\text { parroquia de San Pablo }\end{array}$ \\
\hline Bosch, Guillem & pelaire & $1459-1460$ & $\begin{array}{l}\text { Miembro de la cofradía de su oficio. Asiste a una } \\
\text { reunión de la misma }\end{array}$ \\
\hline Bra, Bernat & pelaire & 1460 & Asiste a una reunión de la cofradía de su oficio \\
\hline Bra, Ramón & pelaire & 1460 & Asiste a una reunión de la cofradía de su oficio \\
\hline Bronchales, Gil de & tejedor & 1458 & Prohombre del oficio \\
\hline Brún, Sancho & tintorero & 1489 & $\begin{array}{l}\text { Recibe una intimación de los veedores del oficio } \\
\text { a través del concejo }\end{array}$ \\
\hline Bual, García de & pelaire & 1494 & $\begin{array}{l}\text { Pleito con la cofradía de su oficio siendo mayor- } \\
\text { domo de la misma }\end{array}$ \\
\hline Burgos, Pedro de & pelaire & 1496 & Casa en la parroquia de la Magdalena \\
\hline Cabañas, Luis de & pelaire & $1459-1460$ & Miembro de la cofradía de su oficio. \\
\hline Cabañas, Pascual de & pelaire & 1460 & Diputado por el oficio para alquilar el batán \\
\hline Calahorra & pelaire & 1496 & $\begin{array}{l}\text { Casa en la calle de la Hilaza, parroquia de San } \\
\text { Pablo }\end{array}$ \\
\hline Camañas, Luis de & pelaire & 1469 & $\begin{array}{l}\text { Diputado para alquilar el batán. Mayordomo del } \\
\text { oficio en un pleito por un molino }\end{array}$ \\
\hline Campos, Juan de & pilatero & 1460 & Arrendador del batán de la cofradía de pelaires \\
\hline Camuz, Antón & tejedor & 1442 & Veedor del oficio \\
\hline Candela, Pedro & tintorero & 1471 & Veedor del oficio \\
\hline Cardiel, Jimeno & pelaire & $1459-1460$ & $\begin{array}{l}\text { Miembro de la cofradía de su oficio. Asiste a una } \\
\text { reunión de la misma }\end{array}$ \\
\hline Cardiel, Juan & pelaire & 1496 & $\begin{array}{l}\text { Casa en la calle de la Hilaza, parroquia de San } \\
\text { Pablo }\end{array}$ \\
\hline Cardiel, Miguel & pelaire & 1491 & Asiste a una asamblea de su oficio \\
\hline Cariñena, Jaime & pelaire & $1460-1471$ & $\begin{array}{l}\text { Asiste a una reunión de la cofradía de su oficio. } \\
\text { Veedor del mismo. }\end{array}$ \\
\hline Cariñena, Juan & tejedor & 1492 & \begin{tabular}{|l|} 
Veedor nuevo del oficio de tejedores \\
\end{tabular} \\
\hline Casanat, Domingo & cardador & 1496 & $\begin{array}{l}\text { Casa en la parroquia de San Felipe citado como } \\
\text { pobre }\end{array}$ \\
\hline Castellano, Juan & tejedor & 1494 & Veedor del oficio \\
\hline Castellón, García de & pelaire & $1469-1477$ & $\begin{array}{l}\text { Mayordomo de la cofradía de su oficio. Arbitra- } \\
\text { dor del pleito entre dicha cofradía y el pelaire } \\
\text { Martín de Pompién }\end{array}$ \\
\hline Catalina & hiladora & 1496 & Casa en la parroquia de Santa María del Pilar \\
\hline Cenella, Bartolomé & pelaire & 1459 & Miembro de la cofradía de su oficio \\
\hline
\end{tabular}




\begin{tabular}{|c|c|c|c|}
\hline Cerdán, Juan & tejedor & 1496 & Casa en la parroquia de la Seo \\
\hline Cerdán, Pedro & pelaire & $1459-1460$ & $\begin{array}{l}\text { Miembro de la cofradía de su oficio. Asiste a una } \\
\text { reunión de la misma }\end{array}$ \\
\hline Cifuentes, Pascual de & pelaire & 1460 & Asistente a una reunión de la cofradía de pelaires \\
\hline Cortés & tejedor & 1496 & Casa en la parroquia de Santa María del Pilar \\
\hline Cosida, Bartolomé de & pelaire & 1459 & Miembro de la cofradía de su oficio \\
\hline Cuesta, Miguel de la & pelaire & 1491-1494 & $\begin{array}{l}\text { Asiste a una asamblea del oficio. Mayordomo del } \\
\text { mismo en el pleito contra el pelaire García de } \\
\text { Bual }\end{array}$ \\
\hline Dagón, Domingo & bajador & 1496 & Veedor del oficio \\
\hline David, Pedro & pelaire & 1459 & Miembro de la cofradía de su oficio \\
\hline Deza, Juan de & pelaire & $1491-1492$ & $\begin{array}{l}\text { Asiste a una asamblea del oficio. Veedor del mis- } \\
\text { mo }\end{array}$ \\
\hline Dios, Pedro de & pelaire & 1459 & Miembro de la cofradía de su oficio \\
\hline Doñán, Pedro & pelaire & 1492 & Carta de franqueza del concejo \\
\hline Dosal, Juan & pelaire & 1460 & $\begin{array}{l}\text { Diputado por el oficio para alquilar el batán de la } \\
\text { cofradía }\end{array}$ \\
\hline Ejea, Arnaldo de & pelaire & 1439 & Veedor del oficio \\
\hline Ejea, Juan de & pelaire & 1460 & Asiste a una reunión de la cofradía de su oficio \\
\hline Erla, Lorenzo de & pelaire & $1491-1492$ & Consejero del oficio. Veedor del mismo \\
\hline Escudero, Bartolomé & tejedor & 1494 & Veedor del oficio \\
\hline Eslava, Juan de & tintorero & 1482 & Veedor del oficio citado como maestre \\
\hline Espés, Ramón & tejedor & 1496 & Mayordomo del oficio \\
\hline Espinosa & tejedor & 1496 & $\begin{array}{l}\text { Casa en la calle de la Hilaza, parroquia de San } \\
\text { Pablo }\end{array}$ \\
\hline Esteban, Juan & pelaire & 1459 & Miembro de la cofradía de su oficio \\
\hline Faruco, Domingo de & pelaire & 1468 & Veedor del oficio \\
\hline Ferrando & bajador & 1496 & $\begin{array}{l}\text { Casa en la calle de la Hilaza, parroquia de San } \\
\text { Pablo, citado como maestre }\end{array}$ \\
\hline Ferrero, Diego de & pelaire & 1496 & Casa en la parroquia de la Seo \\
\hline Fierro, Guillem del & tejedor & 1458 & Prohombre del oficio \\
\hline Fierro, Sancho del & pelaire & $1459-1491$ & $\begin{array}{l}\text { Miembro de la cofradía de su oficio. Asiste a una } \\
\text { asamblea del mismo }\end{array}$ \\
\hline Formental, Tomás de & cardador & $1490-1496$ & $\begin{array}{l}\text { Carta de franqueza del concejo. Casa en la calle } \\
\text { de la Hilaza, parroquia de San Pablo, citado co- } \\
\text { mo maestre Tomás }\end{array}$ \\
\hline Galdamez, Juan de & pelaire & 1496 & Casa en la parroquia de la Santa Cruz \\
\hline Galdamez, Pedro de & pelaire & 1491 & Asiste a una asamblea de su oficio \\
\hline Galve, Juan de & pelaire & 1460 & Asiste a una reunión de la cofradía de su oficio \\
\hline Garay, Pedro & pelaire & 1491 & Asiste a una asamblea de su oficio \\
\hline Garcés, Juan & tejedor & 1496 & Casa en la parroquia de la Magdalena \\
\hline García, Rodrigo & pelaire & 1459 & Miembro de la cofradía de su oficio \\
\hline Gascón, Bartolomé & pelaire & 1459 & Miembro de la cofradía de su oficio \\
\hline Gastón, Pedro & pelaire & 1496 & Casa en la parroquia de San Pedro \\
\hline Gavín, Domingo & pelaire & $1459-1460$ & $\begin{array}{l}\text { Mayordomo de la cofradía de su oficio. Asiste } \\
\text { como tal a una reunión }\end{array}$ \\
\hline Gómez, Juan & pelaire & $1459-1460$ & $\begin{array}{l}\text { Miembro de la cofradía de su oficio. Consejero } \\
\text { de la misma }\end{array}$ \\
\hline Gonzalbo, Fernando & pelaire & $1459-1477$ & $\begin{array}{l}\text { Miembro de la cofradía de su oficio. Arbitrador } \\
\text { del pleito entre dicha cofradía y el pelaire Martín } \\
\text { de Pompién }\end{array}$ \\
\hline Gonzálvez, Juan & bajador & 1454 & Fundador de la cofradía de su oficio \\
\hline
\end{tabular}




\begin{tabular}{|c|c|c|c|}
\hline Gualdarás, Bernat de & pelaire & $1469-1471$ & $\begin{array}{l}\text { Mayordomo de la cofradía de su oficio. Veedor } \\
\text { del mismo }\end{array}$ \\
\hline Guerra, Juan & pelaire & $1459-1460$ & $\begin{array}{l}\text { Miembro de la cofradía de su oficio. Asiste a una } \\
\text { reunión de la misma }\end{array}$ \\
\hline Guillén & pelaire & 1496 & Casa en la parroquia de San Felipe \\
\hline Gurrea, Mateo de & $\begin{array}{l}\text { tejedor y } \\
\text { pelaire }\end{array}$ & $1458-1491$ & $\begin{array}{l}\text { Prohombre del oficio de tejedores. Asiste a una } \\
\text { asamblea del oficio de pelaires }\end{array}$ \\
\hline Ibáñez, Pascual & pelaire & 1493 & $\begin{array}{l}\text { Avecindado en la ciudad procedente de la villa de } \\
\text { Aranda }\end{array}$ \\
\hline Jaime & tejedor & 1496 & $\begin{array}{l}\text { Casa en la parroquia de San Miguel citado como } \\
\text { maestre }\end{array}$ \\
\hline Jaime & tejedor & 1496 & $\begin{array}{l}\text { Casa en la parroquia de San Miguel citado como } \\
\text { maestre y pobre }\end{array}$ \\
\hline Juan & pelaire & 1496 & Casa en la parroquia de San Miguel \\
\hline Juan & tejedor & 1496 & $\begin{array}{l}\text { Casa en la calle del Hospital, parroquia de San } \\
\text { Pablo }\end{array}$ \\
\hline Juan & tejedor & 1496 & Casa en la parroquia de San Miguel \\
\hline Juan & tejedor & 1496 & $\begin{array}{l}\text { Casa en la parroquia de la Magdalena citado co- } \\
\text { mo pobre }\end{array}$ \\
\hline Juan, la viuda de & pelaire & 1496 & $\begin{array}{l}\text { Casa en la calle de la Hilaza, parroquia de San } \\
\text { Pablo }\end{array}$ \\
\hline Juanco, la viuda de & lanero & 1496 & Casa en la parroquia de la Santa Cruz \\
\hline Julián, Jaime & tejedor & 1496 & $\begin{array}{l}\text { Casa en la calle de la Castellana, parroquia de } \\
\text { San Pablo }\end{array}$ \\
\hline Laguna, Antón de la & tejedor & $1468-1492$ & $\begin{array}{l}\text { Veedor del oficio. Sustituye al veedor difunto } \\
\text { Gonzalo de Santa María }\end{array}$ \\
\hline Ledesma, Juan de & tintorero & 1440 & Veedor del oficio \\
\hline Leiza, García de & pelaire & $1491-1496$ & $\begin{array}{l}\text { Asiste a una asamblea de su oficio. Dos casas en } \\
\text { la calle de la Hilaza, parroquia de San Pablo, ci- } \\
\text { tado en una de ellas sólo como García }\end{array}$ \\
\hline Leiza, Sancho de & pelaire & 1491 & Asiste a una asamblea de su oficio \\
\hline Lerma, Juan de & bajador & 1454 & Fundador de la cofradía de su oficio \\
\hline Lobera & hilador & 1496 & $\begin{array}{l}\text { Casa en la calle de la Hilaza, parroquia de San } \\
\text { Pablo, citada como las hilanderas de Lobera }\end{array}$ \\
\hline Lobreto, Guillem & bajador & 1454 & Fundador de la cofradía de su oficio \\
\hline Logroño, Diego de & pelaire & 1460 & Asiste a una reunión de la cofradía de ss \\
\hline Logroño, Martín de & pelaire & 1459 & Miembro de la cofradía de su oficio \\
\hline Lope & bajador & 1496 & $\begin{array}{l}\text { Casa en la parroquia de San Gil citado como } \\
\text { maestre }\end{array}$ \\
\hline López, Jaime & trapero & 1496 & Jura el estatuto de traperos y sastres \\
\hline Lorca & tejedor & 1496 & $\begin{array}{l}\text { Casa en la calle de las Armas, parroquia de San } \\
\text { Pablo }\end{array}$ \\
\hline Loscos, Bartolomé de & tejedor & $1439-1468$ & $\begin{array}{l}\text { Veedor del oficio. Prohombre del mismo en } \\
\text { 1458. Veedor otra vez. }\end{array}$ \\
\hline Macián & tejedor & 1496 & Casa en la parroquia de San Felipe \\
\hline Maestre, Juan & tejedor & 1472 & Mayordomo del oficio \\
\hline Magallón, Juan de & tejedor & 1458 & Prohombre del oficio \\
\hline Mañas, Domingo & pelaire & 1459 & Miembro de la cofradía de su oficio \\
\hline Marlás, Domingo & tejedor & 1439 & Veedor del oficio \\
\hline Marquilla, Juan de & pelaire & 1496 & $\begin{array}{l}\text { Casa en la calle de la Hilaza, parroquia de San } \\
\text { Pablo }\end{array}$ \\
\hline Martín & peinador & 1496 & $\begin{array}{l}\text { Casa en el barrio nuevo de la parroquia de San } \\
\text { Lorenzo }\end{array}$ \\
\hline
\end{tabular}




\begin{tabular}{|c|c|c|c|}
\hline Martín & tejedor & 1496 & $\begin{array}{l}\text { Casa en la calle del Hospital, parroquia de San } \\
\text { Pablo }\end{array}$ \\
\hline $\begin{array}{l}\text { Masparança, Guillem } \\
\text { de }\end{array}$ & pelaire & 1459 & Miembro de la cofradía de su oficio \\
\hline Medina, Aparicio & pelaire & 1491 & Asiste a una asamblea de su oficio \\
\hline Miguel & tejedor & 1496 & Casa en la parroquia de San Gil \\
\hline Miguel & tintorero & 1496 & $\begin{array}{l}\text { Casa en la parroquia de Santa María de Altabás } \\
\text { citado como maestre }\end{array}$ \\
\hline Miguel, la viuda de & tejedor & 1496 & $\begin{array}{l}\text { Casa en la calle de la Castellana, parroquia de } \\
\text { San Pablo }\end{array}$ \\
\hline Milián, Martín & pelaire & 1496 & Casa en la parroquia de la Magdalena \\
\hline Miranda, Francisco & pelaire & $1459-1491$ & $\begin{array}{l}\text { Miembro de la cofradía de su oficio. Diputado en } \\
1460 \text { para alquilar el batán de la cofradía. Veedor } \\
\text { del oficio en } 1468 \text {. Mayordomo del mismo en una } \\
\text { asamblea de } 1491\end{array}$ \\
\hline Moliner, Domingo & tintorero & 1442 & Veedor del oficio \\
\hline Montalbán, Pedro de & tejedor & $1472-1492$ & $\begin{array}{l}\text { Sancionado por tener peines de tamaño inferior a } \\
\text { los permitidos por las ordenanzas. Mayordomo } \\
\text { del oficio }\end{array}$ \\
\hline Montañés, Antón & tejedor & $1490-1496$ & $\begin{array}{l}\text { Carta de franqueza del concejo. Casa en la calle } \\
\text { de la Hilaza, parroquia de San Pablo }\end{array}$ \\
\hline Montañés, Juan & tejedor & 1490 & Carta de franqueza del concejo \\
\hline Moreno, Antón & tintorero & $1442-1490$ & $\begin{array}{l}\text { Veedor del oficio. Condenado a pagar } 11 \text { florines } \\
\text { de oro a un corredor siendo citado como maestre }\end{array}$ \\
\hline Moya & bajador & 1496 & Casa en la parroquia de San Gil \\
\hline Muñoz, Pascual & bajador & 1454 & Fundador y procurador de la cofradía de su oficio \\
\hline Murero, Francisco & pelaire & 1491 & Asiste a una asamblea de su oficio \\
\hline Navarret, Juan de & tejedor & 1458 & Prohombre del oficio \\
\hline Navarro, Domingo & pelaire & $1492-1496$ & $\begin{array}{l}\text { Licencia de armas del concejo. Veedor del oficio } \\
\text { en } 1494 \text {. Casa en la parroquia de San Gil citado } \\
\text { como Navarro }\end{array}$ \\
\hline Navarro, Juan & pelaire & $1459-1496$ & $\begin{array}{l}\text { Miembro de la cofradía de su oficio. Casa en la } \\
\text { calle de la Hilaza, parroquia de San Pablo }\end{array}$ \\
\hline Navas, Fernando de & tejedor & $1494-1496$ & Veedor del oficio. Mayordomo del mismo \\
\hline Nieva, Pedro de & pelaire & $1491-1496$ & $\begin{array}{l}\text { Asiste a una asamblea de su oficio. Casa en la } \\
\text { calle de la Hilaza, parroquia de San Pablo }\end{array}$ \\
\hline Nogueras, Arnau de & cardador & 1496 & $\begin{array}{l}\text { Carta de franqueza del concejo. Casa en la calle } \\
\text { de la Hilaza, parr. de San Pablo, citado como } \\
\text { maestre Arnau }\end{array}$ \\
\hline Nogueras, Jaime de & pelaire & 1459 & Miembro de la cofradía de su oficio \\
\hline Nogueras, Martín de & pelaire & 1439 & Veedor del oficio \\
\hline Nogueras, Miguel de & pelaire & 1460 & $\begin{array}{l}\text { Diputado por el oficio para alquilar el batán de la } \\
\text { cofradía }\end{array}$ \\
\hline Olite, Juan de & bajador & 1454 & Fundador de la cofradía de su oficio \\
\hline Olite, Pedro de & bajador & 1454 & Fundador de la cofradía de su oficio \\
\hline Olite, Salvador de & tejedor & 1491 & Carta de franqueza del concejo \\
\hline Oviedo, Álvaro de & bajador & $1459-1496$ & $\begin{array}{l}\text { Miembro de la cofradía de pelaires y bajadores. } \\
\text { Casa en la calle de la Hilaza, parroquia de San } \\
\text { Pablo }\end{array}$ \\
\hline Oviedo, Juan de & pelaire & $1488-1496$ & $\begin{array}{l}\text { Mayordomo del oficio en un pleito de la cofradía, } \\
\text { citado como propietario de unas casas en la pa- } \\
\text { rroquia de la Magdalena. Veedor del oficio en } \\
1490 \text { y } 1496\end{array}$ \\
\hline
\end{tabular}




\begin{tabular}{|c|c|c|c|}
\hline Palacio, Juan de & pelaire & $1442-1490$ & $\begin{array}{l}\text { Mayordomo del oficio. Sustituye en el cargo al } \\
\text { veedor Francisco de Soria en } 1468 \text {. Veedor del } \\
\text { oficio }\end{array}$ \\
\hline $\begin{array}{l}\text { Palenzuela, Bartolomé } \\
\text { de }\end{array}$ & tejedor & 1458 & Prohombre del oficio \\
\hline Palomar, Juan de & pelaire & $1491-1496$ & $\begin{array}{l}\text { Asiste a una asamblea de su oficio. Casa en la } \\
\text { parroquia de la Santa Cruz }\end{array}$ \\
\hline Peco, García el & pelaire & $1459-1460$ & $\begin{array}{l}\text { Miembro de la cofradía de su oficio. Asiste a una } \\
\text { reunión de la misma }\end{array}$ \\
\hline Pedro & bajador & 1496 & $\begin{array}{l}\text { Casa en la calle de la Hilaza, parroquia de San } \\
\text { Pablo }\end{array}$ \\
\hline Pedro & peinador & 1496 & $\begin{array}{l}\text { Casa en la parroquia de Santa María del Pilar } \\
\text { citado como maestre }\end{array}$ \\
\hline Pedro & pelaire & 1496 & $\begin{array}{l}\text { Casa en la calle de la Castellana, parroquia de } \\
\text { San Pablo }\end{array}$ \\
\hline Pedro & pelaire & 1496 & Casa en la parroquia de San Lorenzo \\
\hline Peña, Miguel de & pelaire & 1459 & Miembro de la cofradía de su oficio \\
\hline Peralta, Antón de & tejedor & 1496 & $\begin{array}{l}\text { Casa en la calle de la Hilaza, parroquia de San } \\
\text { Pablo }\end{array}$ \\
\hline Peralta, Juan de & pelaire & 1491 & Asiste a una asamblea de su oficio \\
\hline Pérez, Francisco & pelaire & $1459-1496$ & $\begin{array}{l}\text { Miembro de la cofradía de su oficio. Casa en la } \\
\text { calle de la Hilaza, parroquia de San Pablo }\end{array}$ \\
\hline Pin, Juan del & tintorero & 1440 & Veedor del oficio \\
\hline Pintano, Martín & pelaire & 1459 & Miembro de la cofradía de su oficio \\
\hline Poca, Juan de & pelaire & 1491 & Asiste a una asamblea de su oficio \\
\hline Polo, Juan & tejedor & 1496 & Veedor del oficio \\
\hline Pompién, Martín de & pelaire & 1477 & $\begin{array}{l}\text { Pleito con la cofradía de pelaires, citado como } \\
\text { escudero y pelaire }\end{array}$ \\
\hline Ramírez, Agustín & bajador & 1454 & Fundador de la cofradía de su oficio \\
\hline Ramo, Domingo de & pelaire & 1460 & Asiste a una reunión de la cofradía de su oficio \\
\hline Ramón & pelaire & 1496 & $\begin{array}{l}\text { Casa en la barrio nuevo de la parroquia de San } \\
\text { Lorenzo }\end{array}$ \\
\hline Ratoner, Juan de & tintorero & 1471 & Veedor del oficio citado como maestre \\
\hline Raz, Juan de la & tintorero & $1439-1442$ & $\begin{array}{l}\text { Diputado del oficio en el reconocimiento de unas } \\
\text { telas. Emparamiento del concejo por sus deudas } \\
\text { con el noble Felipe de Castro }\end{array}$ \\
\hline Requena, Fernando de & tintorero & 1440 & Veedor del oficio \\
\hline Río, Pedro del & pelaire & 1491 & Consejero del oficio \\
\hline Roca, Juan & tejedor & 1496 & Casa en la parroquia de San Felipe \\
\hline Roda, Bernat de & trapero & 1496 & $\begin{array}{l}\text { Propietario de una trapería cuyo regente es Jaime } \\
\text { Samper }\end{array}$ \\
\hline Roda, Pedro de & pelaire & 1496 & $\begin{array}{l}\text { Casa en la calle de la Hilaza, parroquia de San } \\
\text { Pablo }\end{array}$ \\
\hline Ródenas, Miguel de & tejedor & 1458 & Prohombre del oficio \\
\hline Romeu, Miguel & pilatero & 1460 & Arrendador del batán de la cofradía de pelaires \\
\hline Roquet, Juan & tejedor & 1458 & Prohombre del oficio \\
\hline Ros, Pedro & pelaire & 1496 & Casa en la parroquia de San Gil \\
\hline Ruiz, Fernando & pelaire & 1496 & Casa en la parroquia de San Lorenzo \\
\hline Ruiz, Jaime & tejedor & 1472 & Mayordomo del oficio \\
\hline Salina, Aparicio de la & pelaire & 1496 & Veedor del oficio \\
\hline Salz, Gil del & tejedor & 1472 & Veedor del oficio \\
\hline Samaniego, Juan de & pelaire & $1491-1496$ & $\begin{array}{l}\text { Asiste a una asamblea de su oficio. Veedor del } \\
\text { oficio }\end{array}$ \\
\hline
\end{tabular}




\begin{tabular}{|c|c|c|c|}
\hline Samper, Jaime & trapero & 1496 & $\begin{array}{l}\text { Jura el estatuto de traperos y sastres en calidad de } \\
\text { regente de la trapería de Bernat de Roda }\end{array}$ \\
\hline San Juan, Pedro de & pelaire & 1496 & Casa en la parroquia de San Gil \\
\hline San Solet & lanero & 1496 & $\begin{array}{l}\text { Casa en la calle de las Armas, parroquia de San } \\
\text { Pablo }\end{array}$ \\
\hline Sancho & bajador & 1496 & $\begin{array}{l}\text { Casa en la calle de las Armas, parroquia de San } \\
\text { Pablo, citado como maestre }\end{array}$ \\
\hline $\begin{array}{l}\text { Sant Soany, Nicolás } \\
\text { de }\end{array}$ & bajador & 1496 & $\begin{array}{l}\text { Casa en la calle de la Hilaza, parroquia de San } \\
\text { Pablo, citado como Colau. Veedor del oficio }\end{array}$ \\
\hline $\begin{array}{l}\text { Santa María, Gonzalo } \\
\text { de }\end{array}$ & tejedor & $1458-1492$ & $\begin{array}{l}\text { Veedor del oficio en } 1458 \text { y } 1492 \text {. En este último } \\
\text { año fallece y es sustituído en el cargo por otro } \\
\text { pelaire }\end{array}$ \\
\hline Santa María, Juan de & bajador & 1454 & Fundador de la cofradía de su oficio \\
\hline Sarnal & tintorero & 1496 & $\begin{array}{l}\text { Casa en la calle de Predicadores, parroquia de } \\
\text { San Pablo }\end{array}$ \\
\hline Sarria, Juan de & pelaire & 1491 & Asiste a una asamblea de su oficio \\
\hline Saz, Salvador de la & bajador & 1454 & Fundador y procurador de la cofradía de su oficio \\
\hline Serra, Amador & pelaire & $1459-1496$ & $\begin{array}{l}\text { Mayordomo de la cofradía de su oficio en } 1459 \text { y } \\
\text { 1460. Casa en la calle de la Hilaza, parroquia de } \\
\text { San Pablo, citado como Amador }\end{array}$ \\
\hline Serrano, Antón & pelaire & 1496 & Carta de franqueza del concejo \\
\hline Sola, Domingo de & tejedor & 1496 & $\begin{array}{l}\text { Casa en la calle de la Hilaza, parroquia de San } \\
\text { Pablo }\end{array}$ \\
\hline Sola, Juan de & pelaire & 1496 & Casa en la parroquia de la Seo \\
\hline Soles, Pedro & bajador & 1492 & Carta de franqueza del concejo \\
\hline Soria, Alfonso de & pelaire & 1471 & $\begin{array}{l}\text { Veedor del oficio. Licencia del concejo para } \\
\text { obrar unas casas suyas en la parroquia de San } \\
\text { Miguel }\end{array}$ \\
\hline Soria, Francisco de & pelaire & $1459-1491$ & $\begin{array}{l}\text { Miembro de la cofradía de su oficio. Veedor del } \\
\text { mismo en } 1468 \text { hasta su cese porque ocupa el } \\
\text { cargo de lugarteniente del alcaide de Alfajarín. } \\
\text { Veedor otra vez en } 1471 \text {. Asiste a una asamblea } \\
\text { del oficio en } 1491\end{array}$ \\
\hline Soria, García de & tejedor & 1458 & Prohombre del oficio \\
\hline Soria, Jimeno de & tejedor & 1496 & $\begin{array}{l}\text { Casa en la calle de San Blas, parroquia de San } \\
\text { Pablo }\end{array}$ \\
\hline Soria, Lope de & pelaire & $1459-1496$ & $\begin{array}{l}\text { Miembro de la cofradía de su oficio. Casa en la } \\
\text { parroquia de la Magdalena }\end{array}$ \\
\hline Soria, Pedro de & tejedor & 1472 & Veedor del oficio \\
\hline Tejedora, la viuda & tejedora & 1496 & $\begin{array}{l}\text { Casa en la calle de Guillén el Inglés, parroquia de } \\
\text { San Pablo }\end{array}$ \\
\hline Tola, Antón de & bajador & 1496 & Mayordomo del oficio \\
\hline Tous, Bernat & pelaire & $1459-1491$ & $\begin{array}{l}\text { Miembro de la cofradía de su oficio. Asiste a una } \\
\text { asamblea del mismo }\end{array}$ \\
\hline Torralba, Pedro & pelaire & 1439 & Veedor del oficio \\
\hline Torre, Antón de la & tejedor & 1496 & $\begin{array}{l}\text { Casa en la calle de Predicadores, parroquia de } \\
\text { San Pablo, citado como Antón }\end{array}$ \\
\hline Torre, Antón de la & tejedor & 1496 & Veedor del oficio \\
\hline Tubo, Pedro de & peinador & 1490 & $\begin{array}{l}\text { Avecindado en la ciudad procedente del lugar de } \\
\text { Pallaruelo }\end{array}$ \\
\hline Urries, Justo de & bajador & 1454 & Fundador de la cofradía de su oficio \\
\hline Vaquero, Antón & pelaire & 1496 & Casa en la parroquia de la Magdalena \\
\hline Via, Bernat & pelaire & $1442-1468$ & Mayordomo del oficio en 1442 y 1468 \\
\hline
\end{tabular}




\begin{tabular}{|l|l|c|l|}
\hline Via, Pedro & bajador & 1496 & $\begin{array}{l}\text { Casa en la calle de la Hilaza, parroquia de San } \\
\text { Pablo }\end{array}$ \\
\hline Via, Ramón & pelaire & 1496 & $\begin{array}{l}\text { Casa en la calle de la Hilaza, parroquia de San } \\
\text { Pablo }\end{array}$ \\
\hline Villarino, Lope de & tejedor & 1468 & Veedor del oficio \\
\hline Vitoria, Antón de & pelaire & 1459 & Miembro de la cofradía de su oficio \\
\hline Zuera, Pedro de & tejedor & 1472 & $\begin{array}{l}\text { Sancionado por tener peines de tamaño inferior a } \\
\text { los permitidos por las ordenanzas del oficio }\end{array}$ \\
\hline
\end{tabular}

